\title{
Phylogeny of Megasporoporia s.lat. and related genera of Poyporaceae: New genera, new species and new combinations
}

\author{
Lira CRS ${ }^{1}$, Alvarenga RLM ${ }^{1 *}$, Soares AMS ${ }^{2}$, Ryvarden L $^{3}$ and Gibertoni TB ${ }^{1}$ \\ ${ }^{1}$ Universidade Federal de Pernambuco, Centro de Biociências, Departamento de Micologia, Av. Avenida da \\ Engenharia, s/n, CEP 50740-600, Recife, Pernambuco, Brazil \\ ${ }^{2}$ Universidade Federal Rural da Amazônia, Centro de Ciências Biológicas, Campus Tomé-Açu, Rodovia PA-451, Km \\ 03 CEP 68.680-000, Tomé-Açu, Pará, Brazil \\ ${ }^{3}$ Department of Biosciences, University of Oslo, Blindern, N-0316, P. O. Box 1045, Oslo, Norway
}

Lira CRS, Alvarenga RLM, Soares AMS, Ryvarden L, Gibertoni TB - Phylogeny of Megasporoporia s.lat. and related genera of Poyporaceae: New genera, new species and new combinations. Mycosphere 12(1), 1262-1289, Doi 10.5943/mycosphere/12/1/16

\begin{abstract}
Several resupinate poroid Polyporaceae with dextrinoid skeletal hyphae and cylindrical, thinwalled basidiospores have been placed in Dichomitus and Megasporoporia. With the inclusion of DNA sequences, mostly from Chinese material, in the phylogeny of the genera, new genera were recognized, i.e., Megasporoporiella and Megasporia. In the current study, Jorgewrightia and Mariorajchenbergia are described as new genera in the Polyporaceae based on phylogenetic analyses of four gene regions: nuc rDNA ITS1-5.8S-ITS (ITS) and partial Large Subunit (28S), Translation Elongation Factor 1-alpha (TEF1), and RNA polymerase II second largest subunit (RPB2), mostly from Brazilian material. These new genera currently accommodate species formerly placed in Cerioporus, Dichomitus, Megasporia, Megasporoporiella and Pachykytospora. Dichomitus, Jorgewrightia, Mariorajchenbergia, Megasporia and Megasporoporia have mostly resupinate pale-colored basidiomata, poroid hymenophore, usually dextrinoid branched skeletal hyphae, and cylindrical basidiospores. These genera are difficult to differentiate on morphology alone and analyses based on sequences from at least two regions (ITS and 28S), as well as information about geographical distribution, are needed to separate them. Megasporia variabilicolor and Megasporoporia neosetulosa are described as new species, and one neotype and 20 new combinations are proposed. Synoptic tables including characteristics for 27 species from the five genera is presented.
\end{abstract}

Keywords - Agaricomycetes - diversity - neotropics - Polyporales

\section{Introduction}

In recent years, circumscription of genera in Polyporaceae has been much improved due to broader sampling, morphological reassessments and phylogenies based in DNA analyses (Binder et al. 2013, Justo et al. 2017, Cui et al. 2019). Multiloci phylogenetic treatments have been provided for large, widespread genera, such as Dichomitus D.A. Reid, typified by Trametes squalens P. Karst., and Megasporoporia Ryvarden \& J.E. Wright, typified by Poria setulosa Henn., which include several species of resupinate, more rarely pileate, poroid fungi with dextrinoid skeletal hyphae and cylindrical, thin-walled basidiospores (Ryvarden et al. 1982, Masuka \& Ryvarden 1999, Dai \& Wu 2004, Zhou \& Dai 2008, Du \& Cui 2009, Gomes-Silva et al. 2012, Li \& Cui 
2013a, b, Yuan 2013, Wang et al. 2021).

Initially, Dichomitus was considered to be allied to Antrodia P. Karst. based on similar morphological characteristics except for the presence of arboriform skeletal hyphae (Ryvarden \& Johansen 1980) in the former. Later, Dichomitus was reevaluated as closer to Polyporus P. Micheli ex Adans. because of the arboriform skeletal hyphae and similar basidiospore morphology (Ryvarden 1991).

Megasporoporia was first assumed to be related to Grammothele Berk. \& M.A. Curtis (Ryvarden et al. 1982) due to the presence of dextrinoid skeletal hyphae, similar basidiospore morphology and presence of dendrohyphidia. However, Ryvarden (1991) suggested a closer alliance to Dichomitus because of the similar basidiomata and basidiospore features. Megasporoporia was eventually reduced to a synonym of Dichomitus, after the dextrinoid reaction was considered a "chemical character of doubtful taxonomic importance at the generic level" (Masuka \& Ryvarden 1999). This synonymization was either accepted (Gomes-Silva et al. 2012) or rejected by other authors (Dai \& Wu 2004, Zhou \& Dai 2008, Du \& Cui 2009, Li \& Cui 2013b, Yuan 2013, Wang et al. 2021).

With the use of analyses of DNA sequences, the separation of Dichomitus and Megasporoporia became evident (Ghobad-Nejhad \& Dai 2010, Binder et al. 2013, Li \& Cui 2013a). Moreover, new clades were delimited and included species with similar characteristics as existing genera, i.e., mostly resupinate, poroid Polyporaceae, with branched and variably dextrinoid skeletal hyphae, variable presence of dendroyphydia, crystals and hyphal pegs, and cylindrical, thin-walled, non-dextrinoid, non-amyloid basidiospores (Ghobad-Nejhad \& Dai 2010, Li \& Cui 2013a). Thus, two new genera were described. Megasporoporiella B.K. Cui, Y.C. Dai \& Hai J. Li, with Polyporus cavernulosus Berk. as type, included five species characterized by large pores, skeletal hyphae dominating the trama, and presence of crystals in the hymenium. Megasporia B.K. Cui, Y.C. Dai \& Hai J. Li, was described with Poria hexagonoides Speg. as type and included seven species similar to those of Megasporoporia, but without hyphal pegs ( $\mathrm{Li} \&$ Cui 2013a). Recently, five new species were added to Megasporia, one to Megasporoporia and one to Megasporoporiella, mostly from China (Yuan et al. 2017, Wang et al. 2021), while Zmitrovich (2018) synonymized Megasporoporiella, among other genera, to Cerioporus Quél.

Li \& Cui (2013a) admitted that the characteristics were insufficient to morphologically distinguish the new genera, i.e., Megasporoporiella and Megasporia, from each other, and from Megasporoporia. Li \& Cui (2013a) concluded that variation in pore size, basidiospore morphology, hyphal system type, and skeletal hyphae reaction in Melzer's reagent could be used to distinguish Megasporia, Megasporoporia and Megasporoporiella from other genera in what is recognized today as Polyporaceae. Species, however, could be distinguished by the presence of dendrohyphidia, hyphal pegs, cystidioles and crystals, even though Li \& Cui (2013a) suggested these features are homoplastic. Later, Yuan et al. (2017) observed that Megasporoporia had ditrimitic hyphal structure and strongly dextrinoid skeletal hyphae, while Megasporoporiella and Megasporia had dimitic hyphal structure and weakly to moderately dextrinoid skeletal hyphae. In addition, Megasporoporiella was distributed in temperate areas, while Megasporia was present in the subtropics and tropics. Nevertheless, Cui et al. (2019) and Wang et al. (2021) could not separate these three genera in their keys.

Brazilian material with the characteristics of Dichomitus s.lat. and Megasporoporia s.lat. has been collected in several biomes in the past years. After morphological and DNA analyses, some of them could not be assigned to known taxa and description of new species and reclassification at the genus level became necessary. Here, we discuss the taxonomic and phylogenetic positions of several resupinate fungi previously placed in Cerioporus, Dichomitus, Megasporia, Megasporoporia, Megasporoporiella, Pachykytospora and in two new genera delimited after the inclusion of Brazilian collections, as well as one from Tanzania. 


\section{Materials \& Methods}

\section{Area of study and morphological studies}

The specimens were collected in Brazilian Amazonia, Caatinga and Atlantic Rain Forest. Other samples previously deposited in the Herbaria of the Departamento de Micologia of UFPE (URM), Departamento de Botânica of UFSC (FLOR), Instituto de Pesquisas Ambientais de São Paulo (SP) and University of Oslo (O) were revised and partly used in molecular analyses.

Specimen were identified or confirmed based on macro- (measures, shape and color of the basidiomata) and micro-morphology (slide preparations with $5 \% \mathrm{KOH}$, stained with $1 \%$ aqueous phloxine, Melzer's reagent and Cotton Blue to analyze the hyphal system, dextrinoid or cyanophylic reaction, presence/absence and measurements of sterile structures and basidiospores) (Ryvarden 1991). The designation of color followed Watling (1969). The following abbreviations are used: $\mathrm{IKI}=$ Melzer's reagent, $\mathrm{IKI}-=$ no reaction, $\mathrm{IKI}+=$ dextrinoid, $\mathrm{KOH}=$ potassium hydroxide, $\mathrm{CB}=$ Cotton Blue, $\mathrm{CB}+=$ cyanophilous, $\mathrm{CB}-=$ acyanophilous, $\mathrm{L}=$ mean spore length (arithmetic average of all measured spores), $\mathrm{W}=$ mean spore width (arithmetic average of all measured spores), $\mathrm{Q}=$ variation in the $\mathrm{L} / \mathrm{W}$ ratios between the specimens studied, and $\mathrm{n}(\mathrm{a} / \mathrm{b})=$ number of spores (a) measured from a given number (b) of specimens.

\section{DNA extraction, PCR amplification and sequencing}

Fragments (1-2 mg) from the basidiomata were removed and placed in tubes of $1.5 \mathrm{ml}$ and stored at $-20^{\circ} \mathrm{C}$ until extraction. The DNA was extracted according to the method described in Goés -Neto et al. (2005). The nuc rDNA Internal Transcribed Spacer (ITS) and partial Large Subunit (nLSU), the Translation Elongation Factor 1-alpha (TEF1) and the RNA Polymerase II Second Largest Subunit (RPB2) were amplified for the sequences generated here using the primer pairs ITS4-ITS5, LR0R-LR5, RPB2 5F-RPB2 7.1R and Ef DF-EF1 2218 R, respectively (White et al. 1990, Moncalvo et al. 2000, Rehner \& Buckley 2005, Frøslev et al. 2005, Smith \& Sivasithamparam 2000). Negative controls containing all components of the reaction mix, but exchanging DNA by water, were used in each procedure to detect possible contamination. The amplification products were purified with GenJET PCR Purification Kit (Thermo Scientific) and sequenced at the Plataforma Tecnológica de Genômica e Expressão Gênica do Centro de Biociências, UFPE, Brazil, and at the Stab Vida, Portugal, both using the Sanger method. Cycle sequencing was carried out with the same primers as the amplification reactions (Moncalvo et al. 2000). All obtained sequences were deposited in GenBank (National Center for Biotechnology Information, Maryland, USA) (Table 1).

\section{Phylogenetic analyses}

The chromatograms were analyzed to check their quality and edited using the STADEN Package 2.0 software (Bonfield et al. 1995). Then, the newly generated sequences were compared with sequences deposited in GenBank (https://www.ncbi.nlm.nih.gov/genbank/). For alignment, we followed the results of Li \& Cui (2013a), Justo et al. (2017), Yuan et al. (2017), and Wang et al. (2021), as well as the most similar sequence from GenBank (Table 1). One data set was prepared with ITS $+28 \mathrm{~S}+\mathrm{RPB} 2+\mathrm{TEF} 1$. Sequence alignment was deposited at TreeBase (submission ID 29066, link to reviewers: http://purl.org/phylo/treebase/phylows/study/TB2:S29066?x-accesscode $=23438728876 \mathrm{fa} 258 \mathrm{df} 1 \mathrm{cba} 366 \mathrm{f} 69 \mathrm{c} 4 \mathrm{~b} 6 \&$ format $=\mathrm{html}$ ). Each locus was aligned using the MAFFT v.7 online interface, under the auto mode strategy [http://mafft.cbrc.jp/alignment/server/, Katoh \& Toh (2008)], then manually improved using MEGA7 (Kumar et al. 2016).

Phylogenetic reconstructions were performed using Maximum Likelihood (ML) and Bayesian Inference (BI) analyses. Nucleotide substitution models for each gene fragment were estimated based on Bayesian Information Criterion (BIC) on W-IQ-TREE (Kalyaanamoorthy et al. 2017) and used for ML and BI analyses.

ML analysis was run in W-IQ-TREE (Trifinopoulos et al. 2016), with 1000 bootstrap replicates (Nguyen et al. 2015) and Ultrafast bootstrap (UFBoot2, Hoang et al. 2017). 
BI analysis was performed using MrBayes v.3.1.2 (Ronquist \& Huelsenbeck 2003), for two independent runs, each with four Markov chains Monte Carlo $\left(\mathrm{MCMC}\right.$ ) independent runs for $5 \times 10^{6}$ generations (split frequencies $=0.011$ ). Statistical support for branches was considered informative with Bayesian posterior probabilities (pp) $\geq 0.90$ and bootstrap (bs) and UFBoot2 (ub)values $\geq 80 \%$. The tree was visualized using FigTree (Rambaut 2014) and the final layout made in Inkscape 2020.

Table 1 Specimens used in this study with vouchers and GenBank accession numbers for the ITS, nLSU, RPB2 and TEF1 sequences. The sequences in bold were generated in this study

\begin{tabular}{|c|c|c|c|c|c|c|c|}
\hline \multirow[t]{2}{*}{ Species } & \multirow[t]{2}{*}{ Sample no. } & \multirow{2}{*}{$\begin{array}{l}\text { Geographic } \\
\text { origin }\end{array}$} & \multicolumn{4}{|c|}{ GenBank } & \multirow[t]{2}{*}{ References } \\
\hline & & & ITS & nLSU & RPB2 & TEF1 & \\
\hline Cerioporus squamosus & Cui 10394 & China & KX851635 & KX851688 & KX851766 & KX851789 & Cui et al. (2019) \\
\hline Cerioporus squamosus & AFTOL-ID 704 & USA & DQ267123 & AY629320 & DQ408120 & DQ028601 & Genbank \\
\hline Cerioporus squamosus & Cui 10595 & China & KU189778 & KU189809 & KU189988 & KU189925 & Zhou et al. (2016) \\
\hline Crassisporu imbricatus & Dai 10788 & China & KC867350 & KC867425 & - & - & Cui et al. (2019) \\
\hline Crassisporu imbricatus & Cui 6556 & China & KC867351 & KC867426 & - & - & Cui et al. (2019) \\
\hline Crassisporus macroporus & Cui 14465 & China & MK116485 & MK116494 & MK122990 & MK122983 & Cui et al. (2019) \\
\hline Crassisporus macroporus & Cui 14468 & China & MK116486 & MK116495 & MK122991 & MK122984 & Cui et al. (2019) \\
\hline Daedaleopsis confragosa & Cui 6556 & China & KU892428 & KU892448 & KU892507 & KX838418 & Cui et al. (2019) \\
\hline Daedaleopsis confragosa & Cui 9756 & China & KU892438 & KU892451 & KU892508 & - & Cui et al. (2019) \\
\hline Daedaleopsis hainanensis & Dai 9268 & China & KU892434 & KU892458 & KU892496 & - & Li et al. (2016) \\
\hline Daedaleopsis hainanensis & Cui 5178 & China & KU892435 & KU892462 & KU892495 & KX838441 & Li et al. (2016) \\
\hline Daedaleopsis purpurea & Dai $13583 a$ & China & KX832054 & KX832063 & KX838480 & KX838440 & Cui et al. (2019) \\
\hline Daedaleopsis purpurea & Dai 8060 & Japan & KU892442 & KU892475 & KU892498 & KX838438 & Li et al. (2016) \\
\hline Datronia mollis & Dai 11456 & China & JX559253 & JX559292 & JX559307 & KX838424 & Li et al. (2014) \\
\hline Datronia mollis & Dai 11253 & China & JX559258 & JX559289 & JX559306 & - & Li et al. (2014) \\
\hline Datronia subtropica & Dai 12885 & China & KC415185 & KC415192 & KC415199 & KX838428 & Li et al. (2014) \\
\hline Datronia subtropicus & Dai 12883 & China & KC415184 & KC415191 & KC415198 & KX838427 & Li et al. (2014) \\
\hline Dichomitus ecuadoriensis & $\begin{array}{l}\text { Ryvarden } 44728 \\
\text { (Holotype) }\end{array}$ & Ecuador & - & JQ780440 & - & - & Li \& Cui (2013a) \\
\hline Dichomitus squalens & - & Sweden & JQ518275 & - & - & - & Carlsson et al. (2012) \\
\hline Dichomitus squalens & LY-AD-421-SS1 & França & KP135330 & - & - & - & $\begin{array}{l}\text { Floudas \& Hibbett } \\
\text { (2015) }\end{array}$ \\
\hline Dichomitus squalens & A-670 & Finland & AM988624 & - & - & - & Genbank \\
\hline Dichomitus squalens & Cui 9639 & China & JQ780407 & JQ780426 & KX838478 & KX838436 & Li \& Cui (2013a) \\
\hline Dichomitus squalens & Cui 9725 & China & JQ780408 & JQ780427 & - & KX838435 & Li \& Cui (2013a) \\
\hline Dichomitus squalens & LE 258894 & Russia & KM411455 & KM411471 & - & KM411486 & $\begin{array}{l}\text { Zmitrovich \& } \\
\text { Kovalenko (2016) }\end{array}$ \\
\hline Echinochaete russiceps & Dai 13868 & China & KX832051 & KX832060 & KX838479 & KX838437 & Cui et al. (2019) \\
\hline
\end{tabular}


Table 1 Continued.

\begin{tabular}{|c|c|c|c|c|c|c|c|}
\hline \multirow[t]{2}{*}{ Species } & \multirow[t]{2}{*}{ Sample no. } & \multirow{2}{*}{$\begin{array}{l}\text { Geographic } \\
\text { origin }\end{array}$} & \multicolumn{4}{|c|}{ GenBank } & \multirow[t]{2}{*}{ References } \\
\hline & & & ITS & nLSU & RPB2 & TEF1 & \\
\hline Echinochaete russiceps & Dai 13866 & China & KX832050 & KX832059 & - & - & Cui et al. (2019) \\
\hline Favolus acervatus & Cui 11053 & China & KU189774 & KU189805 & KU189994 & KU189920 & Zhou \& Cui 2017 \\
\hline Favolus acervatus & Dai $10749 b$ & China & KX548953 & KX548979 & KX549073 & KX549043 & Zhou \& Cui (2017) \\
\hline Favolus niveus & Cui 11129 & China & KX548955 & KX548981 & KX549074 & KX549045 & Zhou \& Cui (2017) \\
\hline Favolus niveus & Dai 13276 & China & KX548956 & KX548982 & - & KX549046 & Zhou \& Cui (2017) \\
\hline Favolus pseudoemerici & Cui 11079 & China & KX548958 & KX548984 & KX549075 & KX549048 & Zhou \& Cui (2017) \\
\hline Favolus pseudoemerici & Cui 13757 & China & KX548959 & KX548985 & - & KX549049 & Zhou \& Cui (2017) \\
\hline Hexagonia glabra & Dai 12993 & China & KX900637 & KX900683 & KF274649 & KX900823 & Cui et al. (2019) \\
\hline Hexagonia glabra & Cui 11367 & China & KX900638 & KX900684 & KX900798 & KX900824 & Cui et al. (2019) \\
\hline Hexagonia tenuis & Niemela-9032 & Zambia & KY948738 & KY948842 & - & - & Justo et al. (2017) \\
\hline Hornodermoporus latissimus & Dai 12054 & China & KX900639 & KX900686 & - & KF286303 & Cui et al. (2019) \\
\hline Hornodermoporus latissimus & Cui 6625 & China & HQ876604 & JF706340 & - & KF181134 & Zhao \& Cui (2012) \\
\hline Hornodermoporus martius & Cui 4055 & China & KX900641 & KX900688 & - & - & Cui et al. (2019) \\
\hline Hornodermoporus martius & Cui 7992 & China & HQ876603 & HQ654114 & - & KF181135 & Zhao \& Cui (2012) \\
\hline Jorgewrightia bambusae & Dai 20064 & China & MW694885 & MW694928 & - & MZ618632 & Wang et al. (2021) \\
\hline Jorgewrightia bambusae & Dai 22106 (Holotype) & China & MW694884 & - & - & MZ618631 & Wang et al. (2021) \\
\hline Jorgewrightia cystidiolophora & Cui 2642 & China & JQ780390 & JQ780432 & - & - & Li \& Cui (2013a) \\
\hline Jorgewrightia cystidiolophora & Cui 2688 (Paratype) & China & JQ780389 & JQ780431 & - & - & Li \& Cui (2013a) \\
\hline Jorgewrightia ellipsoidea & Cui 5222 (Holotype) & China & JQ314367 & JQ314390 & - & - & Li \& Cui (2013a) \\
\hline Jorgewrightia ellipsoidea & Dai 19743 & China & MW694879 & MW694923 & - & - & Wang et al. (2021) \\
\hline Jorgewrightia fusiformis & Dai 18596 (Holotype) & Malaysia & MW694892 & MW694935 & - & MZ618637 & Wang et al. (2021) \\
\hline Jorgewrightia fusiformis & Dai 18578 & Malaysia & MW694893 & MW694936 & - & MZ618638 & Wang et al. (2021) \\
\hline Jorgewrightia guangdongensis & Cui 13986 & China & MG847208 & MG847217 & MG867680 & MG867699 & Cui et al. (2019) \\
\hline Jorgewrightia guangdongensis & Cui 9130 (Holotype) & China & JQ314373 & JQ780428 & - & - & Li \& Cui (2013a) \\
\hline Jorgewrightia hengduanensis & Cui 8076 (Holotype) & China & JQ780392 & JQ780433 & KX900805 & KF286337 & Li \& Cui (2013a) \\
\hline Jorgewrightia hengduanensis & Cui 8176 & China & JQ314370 & KX900697 & KX900806 & MG867700 & Li \& Cui (2013a) \\
\hline Jorgewrightia major & Cui 10253 & China & JQ314366 & JQ780437 & JX559314 & - & Li \& Cui (2013a) \\
\hline Jorgewrightia major & Yuan 1183 & China & JQ314365 & - & - & - & Li \& Cui (2013a) \\
\hline Jorgewrightia rimosa & Dai 21997 & China & MW422262 & - & - & - & Wang et al. (2021) \\
\hline Jorgewrightia rimosa & Dai 15357 (Holotype) & China & KY449436 & KY449447 & - & - & Yuan et al. (2017) \\
\hline Jorgewrightia sp. & Cui 6592 & China & JQ780402 & JQ780438 & - & - & Li \& Cui (2013a) \\
\hline Jorgewrightia sp. & Cui 13855 & China & MG847209 & MG847218 & MG867681 & MG867701 & Li \& Cui (2013a) \\
\hline Jorgewrightia sp. & He 2608 & - & JQ314368 & JQ314388 & - & - & Li \& Cui (2013a) \\
\hline Jorgewrightia sp. & Cui 13853 & China & MW694880 & MW694924 & - & MZ618625 & Wang et al. (2021) \\
\hline Jorgewrightia tropica & Cui 13740 & China & KY449438 & KY449449 & - & MZ618629 & Yuan et al. (2017) \\
\hline
\end{tabular}


Table 1 Continued.

\begin{tabular}{|c|c|c|c|c|c|c|c|}
\hline \multirow[t]{2}{*}{ Species } & \multirow[t]{2}{*}{ Sample no. } & \multirow{2}{*}{$\begin{array}{l}\text { Geographic } \\
\text { origin }\end{array}$} & \multicolumn{4}{|c|}{ GenBank } & \multirow[t]{2}{*}{ References } \\
\hline & & & ITS & nLSU & RPB2 & TEF1 & \\
\hline Jorgewrightia tropica & Cui 13660 (Holotype) & China & KY449437 & KY449448 & - & MZ618630 & Yuan et al. (2017) \\
\hline Jorgewrightia violacea & Cui 13845 & China & MG847211 & MG847220 & MG867683 & MG867703 & Cui et al. (2019) \\
\hline Jorgewrightia violacea & Cui 13838 & China & MG847210 & MG847219 & MG867682 & MG867702 & Cui et al. (2019) \\
\hline Jorgewrightia violacea & Cui 6570 (Holotype) & China & JQ780393 & - & - & - & Li \& Cui (2013a) \\
\hline Jorgewrightia yunnanensis & Dai 13870 (Holotype) & China & KY449443 & KY449454 & - & - & Yuan et al. (2017) \\
\hline Jorgewrightia yunnanensis & Cui 12614A & China & KY449442 & KY449453 & - & MZ618628 & Yuan et al. (2017) \\
\hline Mariorajchenbergia australiae & Dai 18657(Holotype) & Australia & MW694888 & MW694931 & - & MZ618634 & Wang et al. (2021) \\
\hline Mariorajchenbergia australiae & Dai 18658 & Australia & MW694889 & MW694932 & - & MZ618635 & Wang et al. (2021) \\
\hline Mariorajchenbergia hubeiensis & Wei 2045 (Holotype) & China & JQ780387 & JQ780421 & - & - & Cui et al. (2019) \\
\hline Mariorajchenbergia hubeiensis & Dai 18102 & China & MW694890 & MW694933 & - & MZ618636 & Wang et al. (2021) \\
\hline Mariorajchenbergia hubeiensis & Dai 18103 & China & MW694891 & MW694934 & - & - & Wang et al. (2021) \\
\hline Mariorajchenbergia pseudocavernulosa & Yuan 1270 (Holotype) & China & JQ314360 & JQ314394 & - & - & Li \& Cui (2013a) \\
\hline Mariorajchenbergia pseudocavernulosa & Dai 19379 & China & MW694882 & - & - & MZ618626 & Wang et al. (2021) \\
\hline Mariorajchenbergia rhododendri & Dai 4226 (Holotype) & China & JQ314356 & JQ314392 & - & - & Li \& Cui (2013a) \\
\hline Mariorajchenbergia rhododendri & Cui 12432 & China & MW694883 & MW694927 & - & MZ618627 & Wang et al. (2021) \\
\hline Mariorajchenbergia subcavernulosa & Cui 14247 & China & MG847213 & MG847222 & MG867685 & MG867705 & Cui et al. (2019) \\
\hline Mariorajchenbergia subcavernulosa & Cui 9252 & China & JQ780378 & JQ780416 & JX559315 & MG867706 & Li \& Cui (2013a) \\
\hline Megasporia amazonica & JV 1407/47 & Costa Rica & KT156707 & - & - & - & Genbank \\
\hline Megasporia amazonica & URM 85601 & Brazil & KX584455 & KX619579 & MT984345 & MW161494 & Present study \\
\hline Megasporia amazonica & URM 87859 & Brazil & MW989394 & MW965595 & - & - & Wang et al. (2021) \\
\hline Megasporia anoectopora & URM 86947 & Brazil & KX584456 & KX619577 & MT984346 & MW045831 & Present study \\
\hline Megasporia anoectopora & URM 83928 & Brazil & KX584457 & KX619580 & MT984347 & MW161495 & Present study \\
\hline Megasporia anoectopora & URM 83838 & Brazil & - & KX619572* & - & - & Present study \\
\hline Megasporia anoectopora & URM 83837 & Brazil & - & KX619583* & - & - & Present study \\
\hline Megasporia cavernulosa & JV 0904/52J & USA & JF894107 & - & - & - & Genbank \\
\hline Megasporia cavernulosa & JV 0904/50J & USA & JF894105 & - & - & - & Genbank \\
\hline Megasporia cavernulosa & JV 0904/81 & USA & MW989395 & - & - & - & Wang et al. (2021) \\
\hline Megasporia cavernulosa & URM 83867 & Brazil & KX584458 & KX619582 & MT984341 & - & Present study \\
\hline Megasporia cylindrospora & Ryvarden 45186 & Belize & - & JQ780439 & - & - & Li \& Cui (2013a) \\
\hline Megasporia hexagonoides & CBS 464.63 & Argentina & - & AY333802 & - & - & Genbank \\
\hline Megasporia mexicana & JV 1806/4J & Honduras & MW989396 & - & - & - & Wang et al. (2021) \\
\hline Megasporia variabilicolor & URM 88369 & Brazil & KX584449 & KX619578 & MT984342 & MW045833 & Present study \\
\hline Megasporia variabilicolor & URM 84769 & Brazil & KX584450 & KX619570 & MT984343 & MW045834 & Present study \\
\hline Megasporia variabilicolor & $\begin{array}{l}\text { URM } 88368 \\
\text { (Holotype) }\end{array}$ & Brazil & KX584448 & KX619574 & MT984344 & MW161496 & Present study \\
\hline
\end{tabular}


Table 1 Continued.

\begin{tabular}{|c|c|c|c|c|c|c|c|}
\hline \multirow[t]{2}{*}{ Species } & \multirow[t]{2}{*}{ Sample no. } & \multirow{2}{*}{$\begin{array}{l}\text { Geographic } \\
\text { origin }\end{array}$} & \multicolumn{4}{|c|}{ GenBank } & \multirow[t]{2}{*}{ References } \\
\hline & & & ITS & nLSU & RPB2 & TEF1 & \\
\hline Megasporia variabilicolor & URM 86249 & Brazil & KX584454 & KX619581 & - & - & Present study \\
\hline Megasporia variabilicolor & URM 83930 & Brazil & KX584453* & KX619569* & - & - & Present study \\
\hline Megasporia variabilicolor & URM 83982 & Brazil & KX584451* & - & - & - & Present study \\
\hline Megasporia variabilicolor & URM 88366 & Brazil & KX584452 & KX619574 & - & - & Present study \\
\hline Megasporoporia bannaensis & Dai 13596 & China & KX900653 & KX900702 & KX900808 & KX900838 & Cui et al. (2019) \\
\hline Megasporoporia bannaensis & Dai 12306 (Holotype) & China & JQ314362 & JQ314379 & - & KF494979 & Li \& Cui (2013a) \\
\hline Megasporoporia inflata & Dai 17882 & Malaysia & MW694886 & MW694929 & - & - & Wang et al. (2021) \\
\hline Megasporoporia inflata & Dai 17478 (Holotype) & Malaysia & MW694887 & MW694930 & - & MZ618633 & Wang et al. (2021) \\
\hline Megasporoporia minor & Dai 12170 (Holotype) & China & JQ314363 & JQ314380 & - & KF494980 & Li \& Cui (2013a) \\
\hline Megasporoporia minor & Dai 18322 & Vietnam & MW694881 & MW694925 & - & MZ618624 & Wang et al. (2021) \\
\hline Megasporoporia minuta & Zhou 120 & China & JX163055 & JX163056 & - & - & Genbank \\
\hline Megasporoporia minuta & Cui 13945 & China & MW989397 & MW965596 & - & - & Wang et al. (2021) \\
\hline Megasporoporia neosetulosa & JV1008/51J & USA & JF894109 & - & - & - & Li \& Cui (2013a) \\
\hline Megasporoporia neosetulosa & JV1008/102J & USA & JF894110 & - & - & - & Li \& Cui (2013a) \\
\hline Megasporoporia neosetulosa & URM 85113 & Brazil & KX584460 & - & - & MW045832 & Present study \\
\hline Megasporoporia neosetulosa & $\begin{array}{l}\text { URM } 85679 \\
\text { (Holotype) }\end{array}$ & Brazil & KX584459 & OL684780 & - & - & Present study \\
\hline Megasporoporia setulosa & LR 9907 (Neotype) & Tanzania & OL678508 & OL684781 & - & - & Present study \\
\hline Microporus affinis & Wu 9806-33 & Taiwan & - & AY351931 & - & - & Genbank \\
\hline Neodatronia gaoligongensis & Cui 8186 & China & JX559268 & JX559285 & - & - & Li et al. (2014) \\
\hline Neodatronia gaoligongensis & Cui 8055 & China & JX559269 & JX559286 & JX559317 & KX900846 & Li et al. (2014) \\
\hline Polyporus arcularius & Cui 10998 & China & KX548973 & KX548995 & KX549077 & KX549059 & Zhou \& Cui (2017) \\
\hline Polyporus arcularius & Cui 11398 & China & KU189766 & KU189797 & KU189980 & KU189911 & Zhou et al. (2016) \\
\hline Polyporus megasporoporus & Yuan 3880 (Holotype) & China & JQ314377 & JQ314395 & - & KF286334 & Li \& Cui (2013a) \\
\hline Polyporus megasporoporus & Yuan 3874 & China & - & MW694926 & - & - & Wang et al. (2021) \\
\hline Polyporus tuberaster & Dai 12462 & China & KU507580 & KU507582 & - & KU507590 & Zhou et al. (2016) \\
\hline Polyporus tuberaster & Dai 11271 & China & KU189769 & KU189800 & KU189983 & KU189914 & Zhou et al. (2016) \\
\hline Polyporus varius & Cui 12249 & China & KU507581 & KU507583 & KU507592 & KU507591 & Zhou et al. (2016) \\
\hline Polyporus varius & Dai 13874 & China & KU189777 & KU189808 & KU189987 & KU189923 & Zhou et al. (2016) \\
\hline Trametes hirsuta & RLG 5133T & USA & JN164941 & JN164801 & JN164854 & JN164891 & Li \& Cui (2013a) \\
\hline Truncospora macrospora & Cui 8106 & China & JX941573 & JX941596 & KX880871 & KX880920 & Zhao \& Cui (2013) \\
\hline Ttrametes ochracea & HHB 13445sp & USA & JN164954 & JN164812 & JN164852 & JN164904 & Li \& Cui (2013a) \\
\hline
\end{tabular}

* Sequences not used in phylogenetic analysis 


\section{Results}

\section{Phylogeny}

Sixteen specimens were sequenced, generating 14 ITS, 14 nLSU, seven RPB2 and seven TEF1 sequences. The concatenated alignment resulted in 3012 positions including gaps, of which 1652 are constant sites and 1191 parsimony-informative. The best-fit models selected were TPM2u+F+I+G4 for ITS, SYM+I+G4 for $\mathrm{nLSU}, \mathrm{TN}+\mathrm{F}+\mathrm{I}+\mathrm{G} 4$ for RPB2, and TIMe+I+G4 for TEF1.

Five different datasets, one for each locus and the concatenated one, were analyzed using ML and BI analyses. No strong conflicts were detected among the datasets, consequently only the analyses from the concatenated data set are presented here. The results of the phylogenetic analyses generated from ML and BI showed similar tree topologies. Thus, the BI trees with bootstrap support values (BS), UFBoot2 (UB) and posterior probabilities (PP) were used to show the results (Fig. 1).

The newly generated sequences are placed in two clades of Polyporaceae: three in Megasporoporia s.str. and nine in a redefined Megasporia, both with strong support (BS $=99.9 \%$; $\mathrm{UB}=83 \% ; \mathrm{PP}=--$ and $\mathrm{BS}=99.5 \% ; \mathrm{UB}=100 ; \mathrm{PP}=0.91$, respectively). The results also support the description of two new species (Fig. 1). In addition, several sequences of species previously placed in Cerioporus, Dichomitus, Megasporia, Megasporoporiella and Pachykytospora are recovered in two strongly supported clades that could not be assigned to known taxa of Polyporaceae (Fig. 1) and are described below as new genera.

Li \& Cui (2013a) typified Megasporoporiella with M. cavernulosa based on the placement of a $28 \mathrm{~S}$ sequence from Chinese material identified as $M$. cavernulosa (Wu 9508-328). However, the type of $M$. cavernulosa originated from Brazilian Amazonia. In our analyses, the ITS, $28 \mathrm{~S}$ and TEF1 sequences of what we consider the true $M$. cavernulosa recently collected in Brazilian Amazonia were placed in the Megasporia clade (Fig. 1). This makes Megasporoporiella a synonym of Megasporia and renders nameless the clade that corresponds to Megasporoporiella sensu Li \& Cui (2013a). Recently, Wang et al. (2021), without further notice, selected $M$. pseudocavernulosa as the type species of Megasporoporiella, because they had discovered that the type specimen (Wu 9508-328) selected by Li \& Cui (2013a) actually represents M. subcavernulosa. This typification does not follow the procedures for changing a genus type outlined in the International Code of Nomenclature for algae, fungi, and plants (Turland 2018), neither has the typification been registered, as required by the same Code. Consequently, the solution suggested by Wang et al. (2021) for Megasporoporiella is not valid. Instead, the new genus Mariorajchenbergia is described below to include $M$. australiae, $M$. hubeiensis, $M$. pseudocavernulosa, $M$. rhododendri and $M$. subcavernulosa.

Megasporia was typified by M. hexagonoides Li \& Cui (2013a), and the species was represented in the phylogeny by sequences from Chinese collections (He 2608 and Cui 6592). The type specimen of $M$. hexagonoides, however, is from Argentina and the inclusion of an Argentinean sequence of $M$. hexagonoides (CBS 464.63, deposited by J.E. Wright) revealed that the clade that corresponds to Megasporia is a different one (Fig. 1). The species placed in Megasporia sensu Li \& Cui (2013a) are now referred to the new genus Jorgewrightia including J. bambusae, J. cystidiolophora, J. ellipsoidea, J. fusiformis, J. guangdongensis, J. major, J. rimosa, $J$. hengduanensis, J. tropica, J. violacea and J. yunnanensis as well the Chinese specimens misidentified as M. hexagonoides (He 2608, Cui 6592, Cui 13853 and Cui 13855), whose identity should be re-examined (Fig. 1).

The addition of the Argentinean sequence of $M$. hexagonoides also indicated that a revised Megasporia includes the neotropical $M$. amazonica, M. anoectopora, $M$. cavernulosa, $M$. cylindrospora, $M$. hexagonoides and the new species M. variabilicolor (described below) (Fig. 1).

At last, Megasporoporia sensu Li \& Cui (2013a) included a specimen identified as $M$. setulosa (MG38, only nLSU), as well as M. bannaensis and M. minor, all from China. With the inclusion of the neotype of $M$. setulosa (designated below), collected in north Tanzania close to the 
type locality, Megasporoporia currently includes, besides the neotype and the Chinese species, the neotropical, new species $M$. neosetulosa (described below) (Fig. 1). Also, the identity of $M$. setulosa (MG38) should be re-examined.

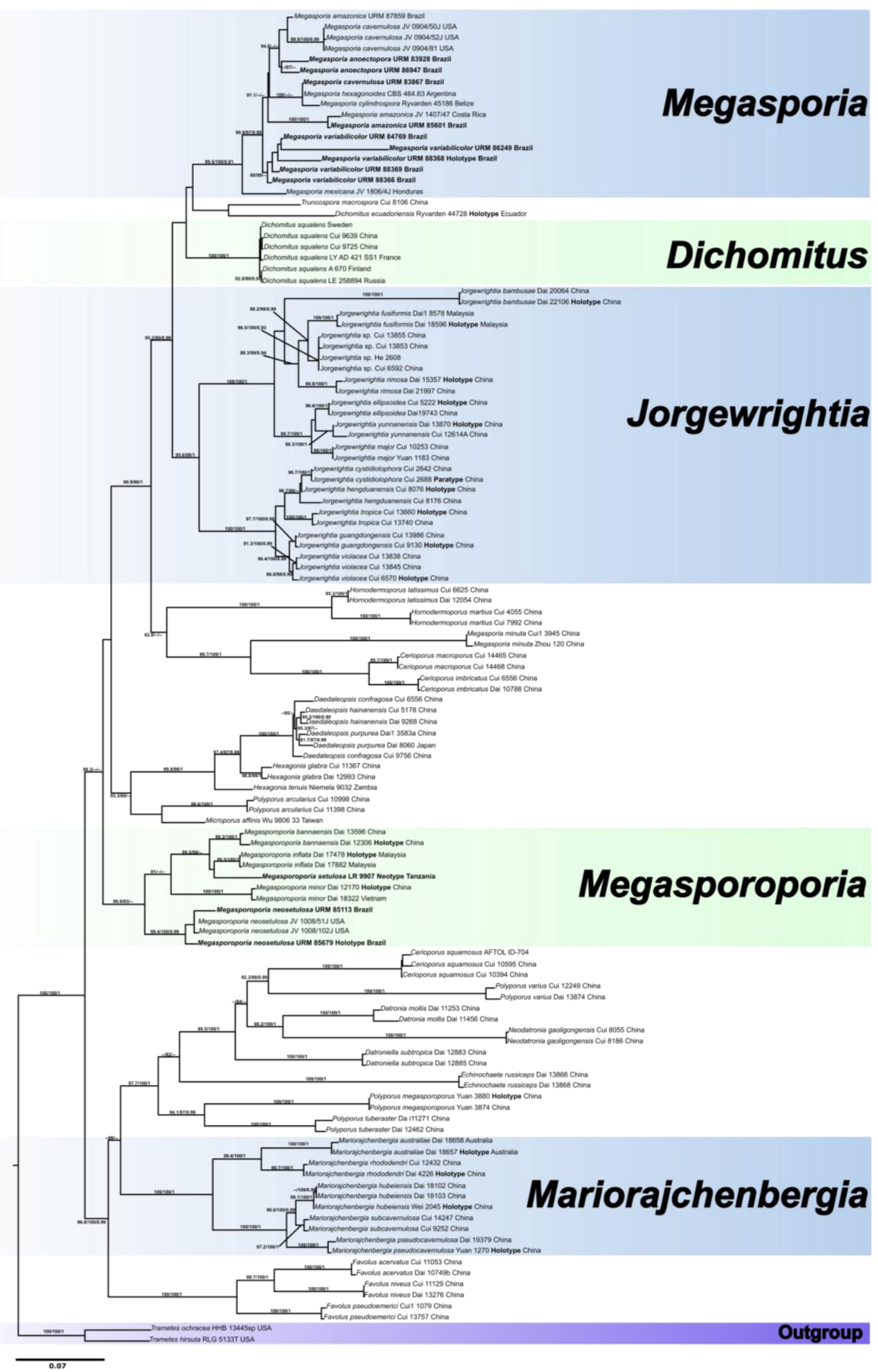

Figure 1 - Phylogenetic reconstruction of Dichomitus, Jorgewrightia, Mariorajchenbergia, Megasporia and Megasporoporia from a combined dataset (ITS + nLSU + RPB2 + tef1) 
sequences. Branches are labeled with ML bootstrap and UFBoot2 $(\geq 80 \%)$ and BA posterior probabilities $(\geq 0.90)$ are shown along the branches, respectively. The sequences in bold were generated for this study.

\section{Taxonomy}

Jorgewrightia Gibertoni \& C.R.S. Lira, gen. nov.

MycoBank number: MB832804

Etym. - Jorgewrightia, in honor of the late Jorge Eduardo Wright renowned Argentinean mycologist.

Basidiomata annual, resupinate. Pore surface white, cream, pale yellowish, honey yellow, salmon, pinkish, ash gray, greyish violet or violet or brown. Pores round to angular, 2-7 per mm. Hyphal system dimitic with clamped generative hyphae, skeletal hyphae non-dextrinoid to strongly dextrinoid, $\mathrm{CB}+$, unbranched to frequently branched. Basidiospores cylindrical, ellipsoid in one species, hyaline, thin-walled, smooth, IKI-, CB-. Polyhedric crystals in the subhymenium and hymenium present in all species except for $J$. yunnanensis. Hyphal pegs present in two species. Dendrohyphidia present in all but four species. Causing white rot on angiosperms. So far, known only from tropical and subtropical China. 2013.

Type species - Megasporia guangdongensis B.K. Cui \& Hai J. Li, Mycologia 105: 371.

Observations - The description above is updated from Megasporia sensu Li \& Cui (2013a) and Yuan et al. (2017), which included M. cystidiolophora, M. elipsoidea, M. guangdongensis, M. hengduanensis, $M$. hexagonoides, $M$. major, $M$. rimosa, $M$. tropica and $M$. violacea.

Jorgewrightia bambusae (Y.C. Dai, Yuan Yuan \& Ya.R. Wang) Gibertoni, comb. nov.

MycoBank number: MB842097

Basionym - Megasporia bambusae Y.C. Dai, Yuan Yuan \& Ya.R. Wang, Mycosphere 12:1020, 2021.

Observations - According to Wang et al. (2021), J. bambusae is distinguished from other species in Megasporoporia s.lat. by its fairly thick-walled basidiospores and by growing on bamboo.

Jorgewrightia cystidiolophora (B. K. Cui \& Y. C. Dai) Gibertoni \& C.R.S. Lira, comb. nov.

MycoBank number: MB832806

Basionym - Megasporoporia cystidiolophora B.K. Cui \& Y.C. Dai, Mikologiya i Fitopatologiya 41: 512, 2007.

Observations - According to Cui \& Dai (2007), this species is distinct by its sterile margin, salmon coloured pore surface when dry, and microscopically by the subulate or ventricose cystidioles, and by lacking hyphal pegs and dendrohyphidia.

Jorgewrightia elipsoidea (B.K. Cui \& P. Du) C.R.S. Lira \& Gibertoni, comb. nov.

MycoBank number: MB832790

Basionym - Megasporoporia ellipsoidea B.K. Cui \& P. Du, Mycotaxon 110: 132. 2009.

Megasporia ellipsoidea (B.K. Cui \& P. Du) B.K. Cui \& Hai J. Li, Mycologia 105: 375. 2013.

Observations - According to Du \& Cui (2009), this species is characterized by its cream to orange yellow pore surface and large pores, calabash-shaped gloeocystidia and ellipsoid basidiospores.

Jorgewrightia fusiformis (Y.C. Dai, Yuan Yuan \& Ya.R. Wang) Gibertoni, comb. nov. MycoBank number: MB842098

Basionym - Megasporia fusiformis Y.C. Dai, Yuan Yuan \& Ya.R. Wang, Mycosphere 12: $1022,2021$. 
Observations - According to Wang et al. (2021), J. fusiformis is distinguished by the fusiform basidiospores. They report both IKI- and IKI+ for the skeletal hypha of this new species.

Jorgewrightia guangdongensis (B.K. Cui \& Hai J. Li) Gibertoni \& C.R.S. Lira, comb. nov.

MycoBank number: MB832807

Basionym - Megasporia guangdongensis B.K. Cui \& Hai J. Li, Mycologia 105: 371, 2013.

Observations - According to Li \& Cui (2013a), this species is characterized by the cream, ash gray, honey yellow or grayish violet pore surface and special cystidioles with collapsed tips and secondary septa.

Jorgewrightia hengduanensis (B.K. Cui \& Hai J. Li) Gibertoni \& C.R.S. Lira, comb. nov.

MycoBank number: MB832808

Basionym - Megasporia hengduanensis B.K. Cui \& Hai J. Li, Mycologia 105: 374, 2013.

Observations - According to Li \& Cui (2013a), this species is characterized by the cream to cream buff pore surface, large pores, almost unbranched skeletal hyphae, and presence of calabashshaped basidia in the hymenium.

Jorgewrightia major (G.Y. Zheng \& Z.S. Bi) C.R.S. Lira \& Gibertoni, comb. nov.

MycoBank number: MB832792 1989.

Basionym - Pachykytospora major G.Y. Zheng \& Z.S. Bi, Acta Mycologica Sinica 8:198,

Megasporia major (G.Y. Zheng \& Z.S. Bi) B.K. Cui \& Hai J. Li, Mycologia 105: 375, 2013.

Observations - According to Dai \& Li (2002), this species is characterized by the cream pore surface, large pores, oblong ellipsoid to subcylindrical basidiospores and presence of hyphal pegs, dendrohyphdia and crystals.

Jorgewrightia rimosa (Y. Yuan, X.H. Ji \& Y.C. Dai) C.R.S. Lira \& Gibertoni, comb. nov.

MycoBank number: MB832793

Basionym: Megasporia rimosa Y. Yuan, X.H. Ji \& Y.C. Dai, MycoKeys 20: 42, 2017.

Observations: According to Yuan et al. (2017), this species is characterized by the extremely thin and cracked basidioma (less than $0.5 \mathrm{~mm}$ thick) when dry.

Jorgewrightia tropica (Y. Yuan, X.H. Ji \& Y.C. Dai) Gibertoni \& C.R.S. Lira, comb. nov.

MycoBank number: MB832809

Basionym - Megasporia tropica Y. Yuan, X.H. Ji \& Y.C. Dai, MycoKeys 20: 44, 2017.

Observations - According to Yuan et al. (2017), this species is characterized by the strongly dextrinoid skeletal hyphae, and by lacking dendrohyphidia, cystidioles and hyphal pegs.

Jorgewrightia violacea (B.K. Cui \& P. Du) Gibertoni \& C.R.S. Lira, comb. nov.

MycoBank number: MB832810

Basionym - Megasporoporia violacea B.K. Cui \& P. Du, Mycotaxon 110: 134, 2009.

Megasporia violacea (B.K. Cui \& P. Du) B.K. Cui, Y.C. Dai \& Hai J. Li, Mycologia $105: 374,2013$

Observations - According to Du \& Cui (2009), this species is unique by its distinct sterile margin, violet to greyish violet pore surface, small pores, presence of both cystidioles and dendrohyphidia, but absence of hyphal pegs.

Jorgewrightia yunnanensis (Y. Yuan, X.H. Ji \& Y.C. Dai) C.R.S. Lira \& Gibertoni, comb. nov. MycoBank number: MB832794

Basionym - Megasporia yunnanensis Y. Yuan, X.H. Ji \& Y.C. Dai, MycoKeys 20: 44, 2017.

Observations - According to Yuan et al. (2017), this species is characterized by the brownish tints on the pore surface and by the absence of tetrahedric or polyhedric crystals. 
Mariorajchenbergia Gibertoni \& C.R.S. Lira, gen. nov.

MycoBank number: MB832795

Etym. - Mariorajchenbergia (Latin), in honor of Mario Rajchenberg, renowned Argentinean mycologist.

Basidiomata annual, resupinate. Pore surface cream, pale yellowish to honey yellow or gray. Pores angular, 1-5 per mm. Hyphal system dimitic with clamped generative hyphae, skeletal hyphae non-dextrinoid to strongly dextrinoid, $\mathrm{CB}+$ (except in M. hubeiensis), moderately to frequently branched. Basidiospores cylindrical to oblong-ellipsoid, ellipsoid in one species, hyaline, thin-walled, smooth, IKI-, CB-. Polyhedric crystals in the subhymenium and hymenium of three species. Hyphal pegs present in three species. Dendrohyphidia present in two species. Causing white rot on angiosperms. So far, known from temperate and subtropical China.

Type species - Megasporoporia subcavernulosa Y.C. Dai \& Sheng H. Wu, Mycotaxon 89: 384. 2004.

Observations - The description above is updated from Megasporoporiella sensu Li \& Cui (2013a), which included M. cavernulosa, M. hubeiensis, M. lacerata, M. pseudocavernulosa, M. rhododendri and $M$. subcavernulosa.

The dextrinoid reaction may be present or absent in the species of Mariorajchenbergia and the reaction is observable right after the preparation of the slides, as usual for species of Megasporoporia s.lat. Cyanophily should be carefully analyzed, not only in Mariorajchenbergia, to certify that the blue coloration takes place in walls and ornamentations of the microstructures and not in the cytoplasm (Lira et al. 2016).

Mariorajchenbergia australiae (Y.C. Dai, Yuan Yuan \& Ya.R. Wang) Gibertoni, comb. nov. MycoBank number: MB 842172

Basionym - Megasporoporiella australiae Y.C. Dai, Yuan Yuan \& Ya.R. Wang, Mycosphere 12: 1027, 2021.

Observations - According to Wang et al. (2021), this species and M. hubeiensis lack dextrinoid skeletal hyphae. From M. hubeiensis, M. australiae can be distinguished by smaller pores.

Mariorajchenbergia hubeiensis (Hai J. Li \& B.K. Cui) Gibertoni \& C.R.S. Lira, comb. nov. MycoBank number: MB832796 2013.

Basionym - Dichomitus hubeiensis Hai J. Li \& B.K. Cui, Nordic Journal of Botany 31: 118,

Megasporoporiella hubeiensis (Hai J. Li \& B.K. Cui) Y.C. Dai, Yuan Yuan \& Ya.R. Wang, Mycosphere 12: 1029, 2021.

Observations - According to Li \& Cui (2013b), this species is distinct by its cream to strawyellow pore surface and large pores, indextrinoid skeletal hyphae, presence of cystidioles and dendrohyphidia in the hymenium, and more or less ellipsoid basidiospores.

Mariorajchenbergia pseudocavernulosa (B.K. Cui \& Hai J. Li) Gibertoni \& C.R.S. Lira, comb. nov.

MycoBank number: MB832799

Basionym - Megasporoporiella pseudocavernulosa B.K. Cui \& Hai J. Li, Mycologia 105: 378, 2013.

Cerioporus pseudocavernulosus (B.K. Cui \& Hai J. Li) Zmitr., Folia Cryptogamica Petropolitana (Sankt-Peterburg) 6: 47, 2018.

Observations - According to Li \& Cui (2013a), this species is easily recognized by its white to cream basidiomata and large and shallow pores.

Mariorajchenbergia rhododendri (Y.C. Dai \& Y.L. Wei) Gibertoni \& C.R.S. Lira, comb. nov. MycoBank number: MB832801 
Basionym - Megasporoporia rhododendri Y.C. Dai \& Y.L. Wei, Annales Botanici Fennici 41: 323, 2004.

Megasporoporiella rhododendri (Y.C. Dai \& Y.L. Wei) B.K. Cui \& Hai J. Li, Mycologia 105:378, 2013.

Cerioporus rhododendri (Y.C. Dai \& Y.L. Wei) Zmitr., Folia Cryptogamica Petropolitana (Sankt-Peterburg) 6:47, 2018.

Observations - According to Dai et al. (2004), this species is characterized by the lack of hyphal pegs, dendrohyphidia and polyhedric crystals. In addition, generative hyphae dominate the tramal structure, the basidiospores are ellipsoid and it grows in boreal forests on fallen trunks and dead trees of Rhododendron.

Mariorajchenbergia subcavernulosa (Y.C. Dai \& Sheng H. Wu) Gibertoni \& C.R.S. Lira, comb. nov.

MycoBank number: MB832803

Basionym - Megasporoporia subcavernulosa Y.C. Dai \& Sheng H. Wu, Mycotaxon 89: 384, 2004.

Megasporoporiella subcavernulosa (Y.C. Dai \& Sheng H. Wu) B.K. Cui \& Hai J. Li, Mycologia 105: 379, 2013.

Cerioporus subcavernulosus (Y.C. Dai \& Sheng H. Wu) Zmitr., Folia Cryptogamica Petropolitana (Sankt-Peterburg) 6: 47, 2018.

Observations - According to Dai \& Wu (2004), this species has both hyphal pegs and dendrohyphidia, and basidiospores distinctly smaller than in Megasporia cavernulosa.

\section{Megasporia B.K. Cui, Y.C. Dai \& Hai J. Li}

Basidiomata annual, resupinate. Pore surface white, cream, ochraceous, pale brown, pale purplish brown or with lavender tints; pores mostly angular, rarely round, 0.5-5 per mm. Hyphal system dimitic with clamped generative hyphae, skeletal hyphae non-dextrinoid to strongly dextrinoid and CB-, unbranched to sparingly branched. Basidiospores cylindrical to ellipsoid, hyaline, thin-walled, smooth, IKI-, CB-. Polyhedric crystals in subhymenium and hymenium in two species, observed in $\mathrm{KOH}$, Melzer's reagent and $\mathrm{CB}$. Hyphal pegs absent, except for few observed in M. mexicana. Dendrohyphidia in M. cavernulosa, difficult to observe. Causing white rot on angiosperms. So far, known from the neotropics.

Type species - Poria hexagonoides Speg., Anales del Museo Nacional de Historia Natural de Buenos Aires 6: 170, 1898 (1899).

Observations - The description above is updated from Megasporia sensu Li \& Cui (2013a) and Yuan et al. (2017). Megasporia can be characterized by the acyanophilous, non-dextrinoid hyphae, which are also unbranched to sparingly branched, usually lack of hyphal pegs and of dendrohyphidia, and the neotropical distribution.

Megasporia variabilicolor C.R.S. Lira \& Gibertoni, sp. nov.

Fig. 2

MycoBank number: MB816410

Etym. - variabilis (Latin), color (Latin), referring to the variable color of basidiomata.

Basidiomata annual, resupinate, easily detachable from the substrate, 1.1-6.2 $\times 0.4-2.8 \times$ 0.2-0.3 mm. Pore surface greyish brown, beige to cream (30 Clay Pink, 32 Clay Buff, 52 Buff), angular pores, (2)3-4(5) per mm, dissepiments thin and entire. Margin sterile, up to $3 \mathrm{~mm}$ width, lighter than the pore surface ( $5 \mathrm{E}$ to $6 \mathrm{~F}$ ). Context very thin, invisible to naked eye, $0.1 \mathrm{~mm}$. Tubes concolorous to the pore surface, up to $3 \mathrm{~mm}$ deep.

Hyphal system dimitic, generative hyphae hyaline, clamped, thin, 2-3 $\mu \mathrm{m}$ diam., thin-walled; skeletal hyphae dominant, dichotomously and moderately branched, weakly to strongly dextrinoid, 2.5-3.5 $\mu \mathrm{m}$ diam., CB-. Large, pyramidal crystals present in the trama and hymenium, 3-5 $\mu \mathrm{m}$. Dendrohyphidia, cystidia, cystidiols and hyphal pegs absent. Basidia clavate to cylindrical, foursterigmate and clamped at the base, $22-30 \times 5-8 \mu \mathrm{m}$. 
Basidiospores cylindrical, hyaline, thin-walled, smooth, (11-)12-13 $\times(2-) 3-4(-5) \mu \mathrm{m}$ $(\mathrm{L}=10.62, \mathrm{~W}=3.42, \mathrm{Q}=3.10, \mathrm{n}=29), \mathrm{IKI}-\mathrm{CB}-$.
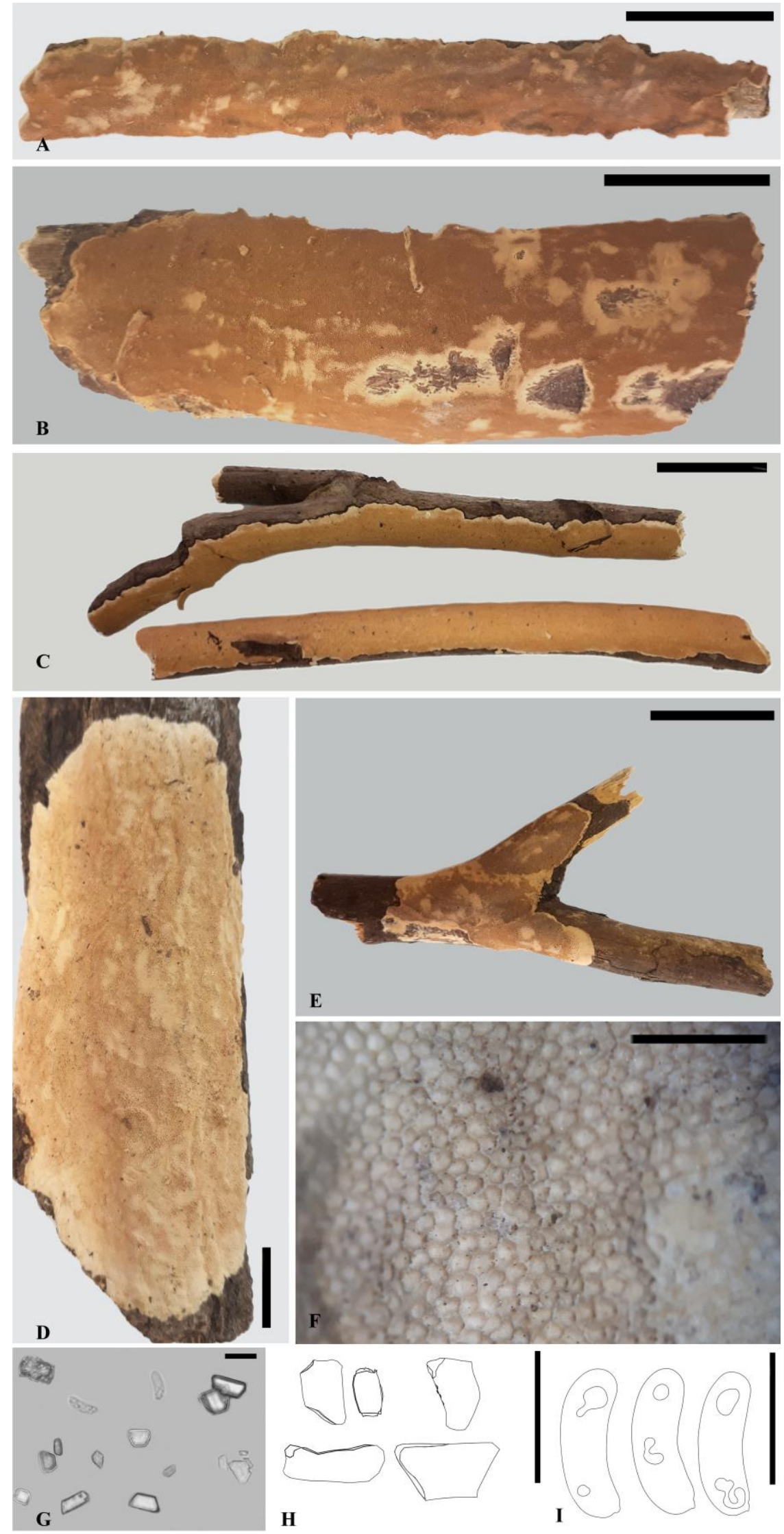

Figure 2 - Megasporia variabilicolor. A-E Basidiomata. A URM 88368 (holotype). B URM 83982. C URM 84769. D URM 88369. E URM 88366. F Pores (URM 88369). G Basidiospores 
and crystals (URM 88369). H Crystals. I Basidiospores. Scale bars: A-E $=2 \mathrm{~cm}, \mathrm{~F}=2 \mathrm{~mm}, \mathrm{G}-\mathrm{I}=$ $10 \mu \mathrm{m}$.

Type specimen - BRAZIL. Paraíba: Areia, Reserva Ecológica Estadual Mata do Pau-Ferro, in dead branch, 17 Jul. 2013, C. R. S. Lira 1095 (URM 88368! - holotype of Megasporia variabilicolor, isotype SP).

Specimens examined - BRAZIL. Ceará: Fortaleza, Parque Botânico do Ceará, 01 Nov. 2010, R.S. Chikowski 09 (URM 88164). Paraíba: Areia, Reserva Ecológica Estadual Mata do Pau-Ferro, 16 Ap. 2012, C. R. S. Lira 624, 630 (URM 83982, URM 83930); 21 Jul. 2012, CRS Lira 206 (URM 84769); 17 Jul. 2013, C. R. S. Lira 1073, 1078 (URM 88369, URM 88366). Pernambuco: Jaqueira, Reserva do Patrimônio Natural Frei Caneca, 08 Mar. 2013, GSN Melo 472 (URM 86249). Rio Grande do Norte, Nísia Floresta, Floresta Nacional de Nísia Floresta, Nov. 2002, T. B. Gibertoni s/n (URM 78071). Sergipe: Itabaiana, Serra de Itabaiana, Jan. 2002, T. B. Gibertoni s/n (URM 78048, 78049).

Additional specimens examined - BRAZIL. Alagoas: Barra de São Miguel, RPPN Rosa do Sol, Oct. 2000, T. B. Gibertoni s/n (URM 78059). Rio Grande do Norte: Baía Formosa, RPPN Senador Antonio Farias - Mata Estrela, Jan. 2002, TB Gibertoni s/n (URM 78079), Mar. 2002, TB Gibertoni s/n (URM 78080), as Dichomitus cavernulosus.

Ecology and distribution - Found on fallen branches of angiosperms in Atlantic Rain Forest and "brejos nordestinos" in Northeast Brazil.

Observations - The phylogeny places this species as a member of the polyporoid clade (Justo et al. 2017) and close to M. hexagonoides, the type of the genus (Li \& Cui 2013a) (Fig. 1). Morphologically, M. variabilicolor is very similar to $M$. cavernulosa, from which it differs by the slightly larger pores $(2-4$ per $\mathrm{mm})$ and basidiospores [(10)12-16 $\times 5-7 \mu \mathrm{m}]$, presence of dendrohyphidia and unbranched hyphae (Table 2,3). Additionally, $M$. cavernulosa seems to have a Northern distribution (Brazilian Amazonia), while M. variabilicolor is so far distributed in the Atlantic Rain Forest and "Brejos Nordestinos" in Northeast Brazil. However, specimens with intermediate characters were found (URM 78059, URM 78079, URM 78080) and should be sequenced for an accurate identification.

Megasporia amazonica (Gomes-Silva, Ryvarden \& Gibertoni) C.R.S. Lira \& Gibertoni, comb. nov.

MycoBank number: MB832797

Basionym - Dichomitus amazonicus Gomes-Silva, Ryvarden \& Gibertoni, Mycological Progress 11: 882, 2012.

Specimens examined - BRAZIL. Amazonas: Manaus, Reserva Ducke, 28 Oct. 2009, L. Ryvarden 48295 (URM 83054 - holotype of Megasporia amazonica). Bahia: Abaíra, Parque Nacional Chapada da Diamantina, 10 Nov. 2015, CRS Lira 03 (URM 87859). Ceará: Tianguá, Serra de Ibiapaba, 18 Apr. 2012, C. R. S. Lira PPBio 704 (URM 83965). Paraíba: Areia, Reserva Ecológica Estadual Mata do Pau-Ferro, 09 Nov. 2010, CRS Lira 12 (URM 84733). Pernambuco: Buíque, Parque Nacional do Catimbau, 31 Jul. 2013, CRS Lira 677 (URM 85601).

Observations - This species is characterized by cream to light brown basidiomata, large pores, and large, ellipsoid to subcylindrical basidiospores (Table 2, 3). It is macroscopically similar to $M$. cavernulosa, which has larger, cylindrical basidiospores. Megasporia amazonica was also collected in Costa Rica (http://mykoweb.prf.jcu.cz/polypores/list_dtof.html). The sequenced collections do not group together (Fig. 1) and, despite being compared and shown to be similar to the type, the Brazilian material should be revaluated, as well as JV1407/47 from Costa Rica, when sequences from the type or material from the type locality are obtained.

Megasporia anoectopora (Berk. \& M.A. Curtis) C.R.S. Lira \& Gibertoni, comb. nov. MycoBank number: MB832800 
Basionym - Polyporus anoectoporus Berk. \& M.A. Curtis, Botanical Journal of the Linnean Society 10: 318, 1869.

Poria anaectopora (Berk. \& M.A. Curtis) Sacc., Sylloge Fungorum 6: 326, 1888.

Dichomitus anoectoporus (Berk. \& M.A. Curtis) Ryvarden, Mycotaxon 20: 331, 1984.

Specimens examined - BRAZIL. Pará: Portel, Floresta Nacional de Caxiuanã, 15 Apr. 2014, A. M. S. Soares-Brandão 562 (URM 86947). Paraíba: Areia, Reserva Ecológica Estadual Mata do Pau-Ferro, 24 Apr. 2013, CRS Lira 570 (URM 85602). Piauí: Caracol, Parque Nacional Serra das Confusões, 15 Mar. 2012, CRS Lira 592, 600 (URM 83838, URM 83928).

Observations - Megasporia anoectopora is characterized by beige to purplish brown basidiomata, large pores and ellipsoid, oblong-ellipsoid basidiospores (Table 2, 3). It is reported from the Caribbean area (Ryvarden 2015) and Brazil (Gomes-Silva et al. 2012).

Megasporia cavernulosa (Berk.) C.R.S. Lira \& Gibertoni, comb. nov.

MycoBank number: MB832802

Basionym - Polyporus cavernulosus Berk., Hooker's Journal of Botany and Kew Garden miscellany 8: 235, 1856.

Poria cavernulosa (Berk.) Sacc., Sylloge Fungorum 6: 324, 1888.

Coriolus cavernulosus (Berk.) Pat., Essai taxonomique sur les familles et les genres des Hyménomycètes (Lons-le-Saunier): 94, 1900.

Megasporoporia cavernulosa (Berk.) Ryvarden, Mycotaxon 16: 174, 1982.

Dichomitus cavernulosus (Berk.) Masuka \& Ryvarden, Mycological Research 103: 1127, 1999. 2013.

Megasporoporiella cavernulosa (Berk.) B.K. Cui, Y.C. Dai \& Hai J. Li, Mycologia 105: 378,

Specimens examined - BRAZIL. Rondônia: Porto Velho, Estação Ecológica de Cuniã, 12 Mar. 2012, A. C. Gomes-Silva and T. B. Gibertoni 17 (URM 83867).

Observations - Megasporia cavernulosa is characterized by pale cream basidiomata, strongly dextrinoid hyphae, and presence of dendrohyphidia (Tables 2,3). The type specimen of this species is from the Brazilian Amazonia, thus reports elsewhere should be revaluated (Ryvarden et al. 1982, Li \& Cui 2013a, Yuan et al. 2017, Cui et al. 2019, Wang et al. 2021). In the phylogeny (Fig. 1), this species clusters with $M$. cylindrospora and $M$. hexagonoides. For the latter, two only LSU sequences are available, which possibly makes the genetic delimitation less reliable. Megasporia cavernulosa, M. cylindrospora and $M$. hexagonoides are all morphologically distinct (Tables 2,3 ) and were originally collected in different ecosystems. In addition, specimens identified as $M$. cavernulosa and collected in Florida (USA) (JV 0904/52J, JV 0904/50J, JV 0904/81, ITS only) do not cluster with the Brazilian M. cavernulosa and may represent another species.

Megasporia cylindrospora (Ryvarden) C.R.S. de Lira \& Gibertoni, comb. nov.

MycoBank number: MB832805

Basionym - Dichomitus cylindrosporus Ryvarden, Synopsis Fungorum 23: 40, 2007.

Specimens examined - BRAZIL. Santa Catarina: Blumenau, Parque Nacional da Serra do Itajaí, 06 Nov. 2011, M. A. B. Silva, E. R. Drechsler-Santos, F. M. Freire and V. F. Lopes 191 (FLOR 49196); ibid, 13 Sep. 2012, M. A. B. Silva, D. H. Costa-Rezende, C. Salvador-Montoya, V.F. Lopes, F.M. Freire. and Demetrio 291 (FLOR 49277). São Paulo: Cananéia, Ilha do Cardoso, 05 Feb. 1987, L. Ryvarden, K. Hjortstam and D. Pegler 24802 (SP-Fungi 466096), São Luiz do Piraitinga, Parque Estadual da Serra do Mar, 29 Jul. 2013, R. M. Pires RP31, RP93 (SP446261, SP213600).

Observations - According to Ryvarden (2007), this species is characterized by narrow, cylindrical basidiospores $(8-10 \times 2.5-3 \mu \mathrm{m})$. Of the examined specimens, only FLOR 49277 had basidiospores, which were slightly longer than originally described $(10-12 \times 2.5-3.5 \mu \mathrm{m})$. Except for SP-Fungi 466096, mostly conical $(25-35 \times 25-35 \mu \mathrm{m})$, occasionally cylindrical $(37 \times 12 \mu \mathrm{m})$ or globose $(35 \times 35 \mu \mathrm{m})$ hyphal pegs were observed, which were not reported in the original 
description. So far, it is known from the type locality in Belize and possibly South and Southeast Brazil.

Megasporia hexagonoides (Speg.) B.K. Cui, Y.C. Dai \& Hai J. Li.

MycoBank number: MB801185

Basionym - Poria hexagonoides Speg., Anales del Museo Nacional de Historia Natural de Buenos Aires 6: 170, 1898, 1899.

Megasporoporia hexagonoides (Speg.) J.E. Wright \& Rajchenb., Mycotaxon 16: 176, 1982.

Dichomitus hexagonoides (Speg.) Robledo \& Rajchenb., Mycotaxon 100: 7, 2007.

Specimens examined - ARGENTINA. Salta: La Viña, 1897, Carlo Spegazzini (O-F-450306, SP); camiño de Rosario de la Frontera a Gobernador Garmendia, Aug. 1963, A. Okada (O-F910700). Tucuman: Dique de Cadillal, 10 Jun. 1951, R. Singer 1568 (O-F-910699, BAFC 27919).

Observations - This species is characterized by ash grey basidiomata with lavender tints, large and hexagonal pores, and cylindrical to slightly allantoid basidiospores (Ryvarden et al. 1982).

Megasporia mexicana (Ryvarden) Gibertoni, comb. nov.

MycoBank number: MB842099

Basionym - Megasporoporia mexicana Ryvarden, Mycotaxon 16: 178, 1982.

Dichomitus mexicanus (Ryvarden) Ryvarden, Synopsis Fungorum 23: 42, 2007.

Observations - This species has the largest basidiospores in the genus and basidiomata with hyphal pegs, although usually few (Ryvarden et al. 1982).

\section{Megasporoporia Ryvarden \& J.E. Wright}

MycoBank number: MB18028

Basidiomata annual, resupinate. Pore surface white, cream, ochraceous or pale brown, pores angular, 0.5-7 per mm. Hyphal system dimitic with clamped generative hyphae, skeletal hyphae strongly dextrinoid, $\mathrm{CB}+$, unbranched to sparingly branched. Basidiospores cylindrical to ellipsoid, hyaline, thin-walled, smooth, IKI-, CB-. Polyhedric crystals in subhymenium and hymenium absent in one species, observed in $\mathrm{KOH}$, Melzer's reagent and $\mathrm{CB}$. Hyphal pegs absent in one species. Dendrohyphidia absent. Causing white rot on angiosperms. So far, known from tropical and subtropical areas.

Type species - Poria setulosa Henn., Botanische Jahrbücher fur Systematik, Pflanzengeschichte und Pflanzengeographie 28:321. 1900.

Neotype - TANZANIA. Arusha province: Arusha National Park, Lake Kusare, Ngurdoto Crater, alt. 1500-1700 m, 3 ${ }^{\circ} 13^{\prime} \mathrm{S}$ and 36 53'E, L. Ryvarden 9907, 7-9 Feb. 1973 (neotypus hic designatus: O-F-503664!, designated here, MBT391367).

Observations - The description above is updated from Megasporoporia sensu Ryvarden et al. (1982), typified by Poria setulosa Henn., collected in Usambara, Tanga Region in Tanzania, and deposited at herbarium B. Ryvarden et al. (1982) stated that the type is lost, probably during World War II. Upon our request, R. Lücking [current curator for cryptogams (lichens, fungi, bryophytes) in herbarium B, pers. comm.] confirmed that the material or similar is absent from herbarium B. Material identified as Megasporoporia setulosa (Henn.) Rajchenb. and also collected in north Tanzania had its DNA sequenced and selected here to be the neotype of $P$. setulosa.

Megasporoporia is characterized by strongly dextrinoid, cyanophilous hyphae, which are also unbranched to sparingly branched, lack of dendrohyphidia, presence of hyphal pegs in most of species, and tropical and subtropical distribution.

Megasporoporia neosetulosa C.R.S. de Lira \& Gibertoni sp. nov.

Fig. 3

MycoBank number: MB835041

Etym. - neosetulosa (Latin), referring to a new species being similar to M. setulosa. 
Basidiomata annual, resupinate, easily detachable from the substrate, $1.8-5.1 \times 0.4-1.6 \times$ 0.1-0.2 mm. Pore surface beige to cream (52 Buff), angular pores, 1.5-2 per mm, dissepiments thin and entire. Margin sterile, up to $1 \mathrm{~mm}$ width, lighter than the pore surface $(6 \mathrm{~F})$. Context very thin, invisible to naked eye, $0.1-0.2 \mathrm{~mm}$. Tubes concolorous to the pore surface, up to $2 \mathrm{~mm}$ deep.

Hyphal system dimitic, generative hyphae hyaline, clamped, thin, 2-3 $\mu \mathrm{m}$ diam., thin-walled; skeletal hyphae dominant, rarely branched, strongly dextrinoid, 2.5-3.5 $\mu \mathrm{m}$ diam., CB+. Pyramidal crystals present in the trama and hymenium, 3-5 $\mu \mathrm{m}$. Dendrohyphidia, cystidia and cystidiols absent. Hyphal pegs present in the hymenium, conical, 62.5-87.5 $\times 20-30 \mu \mathrm{m}$. Basidia not seen. Basidiospores rare, cylindrical, hyaline, thin-walled, smooth, 10-12 × 3-4 $\mu \mathrm{m}$, IKI-, CB-.
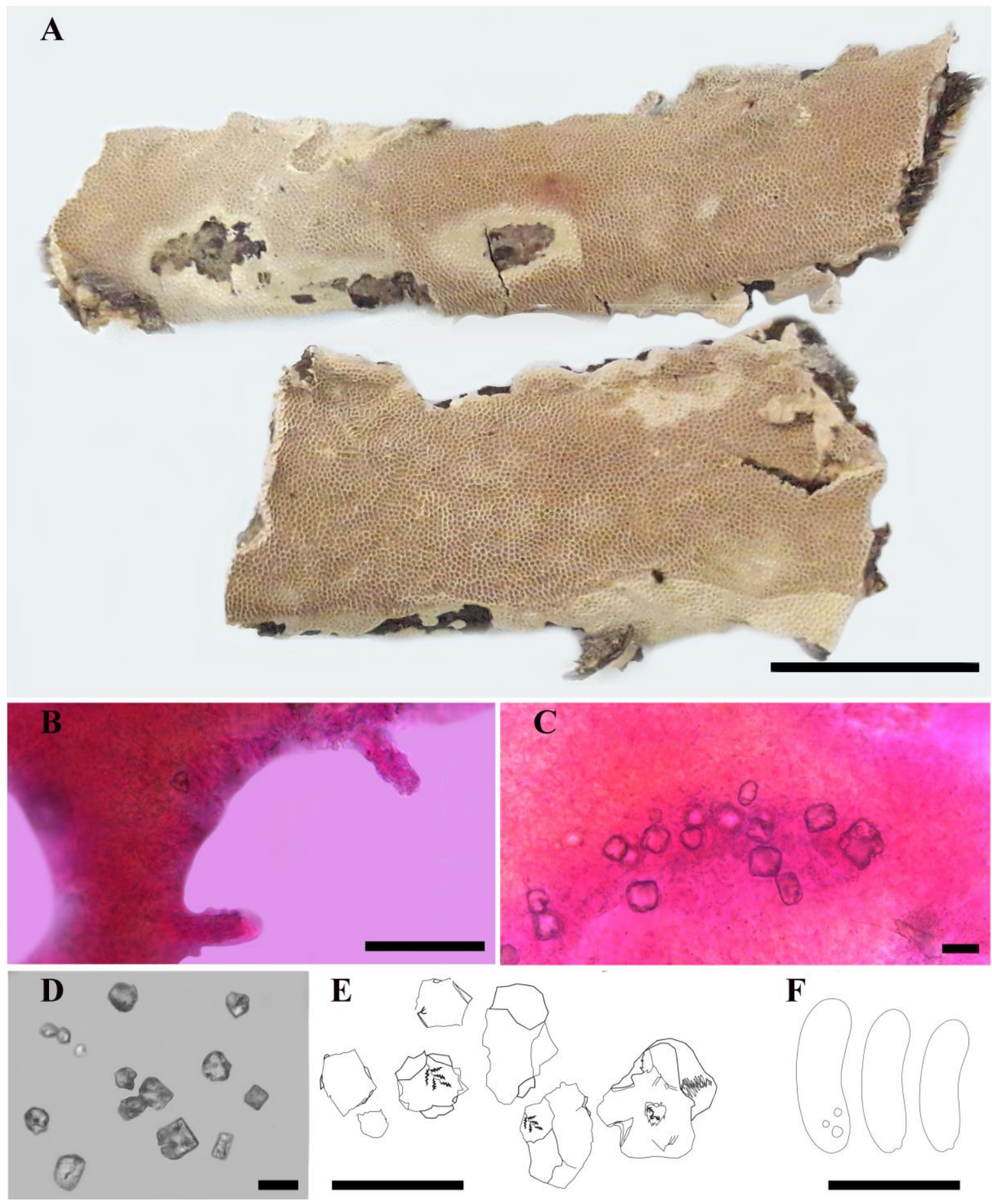

Figure 3 - Megasporoporia neosetulosa (URM 85679, holotype). A Basidiomata. B Hyphal pegs. C Crystals. D, E Crystals. F Basidiospores. Scales bars: A $=1 \mathrm{~cm}, \mathrm{~B}=100 \mu \mathrm{m}, \mathrm{C}-\mathrm{F}=10 \mu \mathrm{m}$. 
Type specimen - BRAZIL. Ceará: Crato, Floresta Nacional do Araripe, 17 May 2012, C. R. S. Lira 934 (URM 85679 ! - holotype of Megasporoporia neosetulosa, isotype SP).

Specimens examined - [most identified as M. setulosa or Dichomitus setulosus (Henn.) Masuka \& Ryvarden]: BRAZIL. Amazonas: Humaitá, 23 Apr. 2013, A. C. Gomes-Silva et al. 109 (URM 87778). Ceará: Crato, Floresta Nacional do Araripe, 25 Jan. 2011, C. R. S. Lira 63 (URM 85111, 85678 ); ibid, 17 May 2012, C. R. S. Lira PPBio 929 (URM 87861); ibid, 17 May 2012, C. R. S. Lira PPBio 939 (URM 87862), Quixadá, RPPN Não Me Deixes, 01 Apr. 2014, CRS Lira 1170 (URM 88006). Pará: Melgaço, Estação Científica Ferreira Penna, Aug. 2007, T. B. Gibertoni w/n (URM 79700), Portel, Floresta Nacional de Caxiuanã, Jan. 2014, AM Soares 1242 (URM 89574); ibid, Sep. 2014, AM Soares 1731 (URM 89575). Paraíba, Areia, Reserva EcológicaEstadual Mata do Pau-Ferro, 29 Apr. 2013, C. R. S. Lira 628 (URM 85113); ibid, 17 Jul. 2013 , CRS Lira 1080 (URM 85680); ibid, 28 Mar. 2014, C. R. S. Lira 885 (URM 87779). Pernambuco: Araripina, Estação Experimental do IPA, 10 Mar. 2008 , ER DrechslerSantos 52PE (URM 80530); Igarassu, 26 Mar. 2015, R. C. Chikowski 13 (URM 90141); ibid, date unknown, R. C. Chikowski 2 (URM 90142); Tamandaré, Reserva Biológica Saltinho, Feb. 2012, L. S. Araujo-Neta and G. S. Nogueira-Melo D18 (URM 87597); ibid, 30 Apr. 2014, R. J. RentoFreitas et al. RF22 (URM 87598); Triunfo, Sítio Carro Quebrado, 20 May 2014, C. R. S. Lira 930 (URM 87904). Piauí: Caracol, Parque Nacional Serra das Confusões, 13 Mar. 2012, CRS Lira 512 (URM 85112). Rondônia: Porto Velho, Parque Circuito, 11 Mar. 2012, A. C. Gomes-Silva and T. B. Gibertoni TB03 (URM 83906, as Grammothele setulosa (Henn.) Ryvarden); ibid, Fazenda Macauã, 27 Jan. 2015, A. M. Soares and S. G. Soares ASR16 (URM 89573); ibid, Sítio Primavera, 10 Nov. 2014, R. C. Chikowski 805 (URM 90174); ibid, Base de Selva Guararapes, 05 Nov. $2015, R$. C. Chikowski 1013 (URM 90175).

Ecology and distribution - Found on fallen branches of angiosperms in Amazonia, Atlantic Rain Forest, "Brejos nordestinos" and "Caatinga" in northeast Brazil, but it may be present in other regions of the neotropics as well.

Observations - The phylogeny places this species as a member of Megasporoporia (Fig. 1). Morphologically, M. neosetulosa is very similar to $M$. setulosa due to the presence of hyphal pegs; however, they differ in the size of basidiospores, slightly larger in the latter $(11-17 \times 4-6 \mu \mathrm{m})$. In addition, M. neosetulosa seems to have a neotropical distribution, while M. setulosa seems to be restricted to Africa so far.

Table 2 Main morphological characteristics of the sequenced species of Dichomitus, Jorgewrightia, Mariorajchenbergia, Megasporia and Megasporoporia. The species in bold represent the type of each genera.

\begin{tabular}{|c|c|c|c|c|}
\hline Genus & Species & Color & Pores $(\mathrm{mm}) / \mathrm{shape}$ & Skeletal hyphae reactions \\
\hline Dichomitus & squalens & $\begin{array}{l}\text { surface white to cream, bay to almost blackish } \\
\text { from the base; pore surface cream to greyish }\end{array}$ & 4-5/round to angular & $\begin{array}{l}\text { arboriform and usually } \\
\text { dichotomously branched } \\
\text { IKI-/CB- }\end{array}$ \\
\hline \multirow[t]{3}{*}{ Jorgewrightia } & bambusae & $\begin{array}{l}\text { white to cream when fresh, cream to buff when } \\
\text { dry }\end{array}$ & 4-5/angular & $\begin{array}{l}\text { frequently branched } \\
\text { weakly IKI+/CB+ }\end{array}$ \\
\hline & cystidiolophora & cream to pale pinkish brown to salmon coloured & $3-5 /$ round to angular & $\begin{array}{l}\text { occasionally branched } \\
\mathrm{IKI}+/ \mathrm{CB}+\end{array}$ \\
\hline & ellipsoidea & $\begin{array}{l}\text { cream buff when fresh, becoming buff to orange } \\
\text { yellow when dry }\end{array}$ & $\begin{array}{l}1-1.5 / \text { round to } \\
\text { angular }\end{array}$ & $\begin{array}{l}\text { rare- to frequently branched } \\
\text { IKI- to weakly }+/ \mathrm{CB}+\end{array}$ \\
\hline
\end{tabular}


Table 2 Continued.

\begin{tabular}{|c|c|c|c|c|}
\hline Genus & Species & Color & Pores $(\mathrm{mm}) / \mathrm{shape}$ & Skeletal hyphae reactions \\
\hline & \multirow[t]{2}{*}{ Fusiformis } & \multirow[t]{2}{*}{ cream when fresh, cream to buff-yellow when dry } & \multirow[t]{2}{*}{$3.5-4 / a n g u l a r$} & frequently branched \\
\hline & & & & IKI- or $+/ \mathrm{CB}+$ \\
\hline & \multirow[t]{2}{*}{ guangdongensis } & \multirow{2}{*}{$\begin{array}{l}\text { cream, ash gray, honey yellow or grayish violet } \\
\text { when dry }\end{array}$} & \multirow[t]{2}{*}{ 4-5/angular } & occasionally branched \\
\hline & & & & $\mathrm{IKI}+/ \mathrm{CB}+$ \\
\hline & \multirow[t]{2}{*}{ hengduanensis } & \multirow[t]{2}{*}{ cream to cream buff when dry } & \multirow[t]{2}{*}{$2-3 /$ round to angular } & rarely branched \\
\hline & & & & $\mathrm{IKI}+/ \mathrm{CB}+$ \\
\hline & \multirow[t]{2}{*}{ major } & \multirow[t]{2}{*}{ cream to wood-colored } & \multirow[t]{2}{*}{ 1-1.5/angular } & ocasionally branched \\
\hline & & & & $\mathrm{IKI}+/ \mathrm{CB}+$ \\
\hline & rimosa & white to cream when fresh, cream when dry & 3-4/angular & $\begin{array}{l}\text { moderately branched in } \\
\text { subiculum, unbranched in tubes } \\
\text { IKI weakly }+/ \mathrm{CB}+\end{array}$ \\
\hline & tropica & clay-pink to fawn when dry & $2-3 /$ round & $\begin{array}{l}\text { Unbranched } \\
\mathrm{IKI}+/ \mathrm{CB}+\end{array}$ \\
\hline & violacea & violet & $5-7 /$ round to angular & $\begin{array}{l}\text { frequently branched } \\
\mathrm{IKI}+/ \mathrm{CB}+\end{array}$ \\
\hline & yunnanensis & white to cream but with brownish tints when dry & $2-3 /$ round & $\begin{array}{l}\text { occasionally branched } \\
\text { IKI weakly }+/ \mathrm{CB}+\end{array}$ \\
\hline \multirow[t]{5}{*}{ Mariorajchenbergia } & australiae & white to cream & $3-4 /$ round to angular & $\begin{array}{l}\text { frequently branched } \\
\text { IKI-/CB+ }\end{array}$ \\
\hline & hubeiensis & cream to straw-yellow & 1-2/angular & $\begin{array}{l}\text { frequently branched } \\
\text { IKI-/CB- }\end{array}$ \\
\hline & pseudocavernulosa & white to cream & 1.5-2.5/angular & $\begin{array}{l}\text { moderately branched } \\
\mathrm{IKI}+/ \mathrm{CB}+\end{array}$ \\
\hline & rhododendri & greyish & 4-5/angular & $\begin{array}{l}\text { moderately branched } \\
\mathrm{IKI}+/ \mathrm{CB}+\end{array}$ \\
\hline & subcavernulosa & cream to pale grayish pore surface & 2-4/angular & $\begin{array}{l}\text { frequently branched } \\
\text { IKI+/CB+ }\end{array}$ \\
\hline \multirow[t]{3}{*}{ Megasporia } & amazonica & pale cream & $\begin{array}{l}\text { 2/angular to } \\
\text { hexagonal }\end{array}$ & $\begin{array}{l}\text { sparingly branched } \\
\text { IKI+/CB- }\end{array}$ \\
\hline & anoectopora & white, tan to pale purplish brown & $1-2 /$ round to angular & $\begin{array}{l}\text { rarely branched } \\
\text { IKI-/CB- }\end{array}$ \\
\hline & cavernulosa & white to cream & $\begin{array}{l}\text { 2-4/angular and } \\
\text { shallow }\end{array}$ & $\begin{array}{l}\text { unbranched and flexuous } \\
\text { IKI+/CB- }\end{array}$ \\
\hline
\end{tabular}


Table 2 Continued.

\begin{tabular}{|c|c|c|c|c|}
\hline Genus & Species & Color & Pores $(\mathrm{mm}) / \mathrm{shape}$ & Skeletal hyphae reactions \\
\hline & cylindrospora & pale brown to ochraceous & 3-4/angular & $\begin{array}{l}\text { arboriform, sparingly branched } \\
\text { IKI- to +/CB- }\end{array}$ \\
\hline & hexagonoides & ash grey with lavender tints & $0.5-1 /$ hexagonal & $\begin{array}{l}\text { branched or not } \\
\mathrm{IKI}+/ \mathrm{CB}-\end{array}$ \\
\hline & mexicana & white to pale cream & $2-3 /$ angular to round & $\begin{array}{l}\text { unbranched, sinuous to } \\
\text { dichotomously branched } \\
\text { IKI+/CB? }\end{array}$ \\
\hline & variabilicolor & beige to cream & $3-4(5) /$ angular & $\begin{array}{l}\text { dichotomously branched } \\
\text { IKI- to +/CB- }\end{array}$ \\
\hline \multirow[t]{5}{*}{ Megasporoporia } & bannaensis & cream to buff when dry & 1-2/angular & $\begin{array}{l}\text { almost unbranched skeletal } \\
\text { hyphae } \\
\text { IKI+/CB+ }\end{array}$ \\
\hline & inflata & cream to clay buff & $\begin{array}{l}2.5-3 / \text { round to } \\
\text { angular }\end{array}$ & $\begin{array}{l}\text { moderately branched } \\
\mathrm{IKI}+/ \mathrm{CB}+\end{array}$ \\
\hline & minor & $\begin{array}{l}\text { cream to buff when fresh, turn to pale brown when } \\
\text { bruised }\end{array}$ & 6-7/angular & $\begin{array}{l}\text { rarely branched } \\
\mathrm{IKI}+/ \mathrm{CB}+\end{array}$ \\
\hline & neosetulosa & beige to cream & 1.5-2/angular & $\begin{array}{l}\text { rarely branched } \\
\mathrm{IKI}+/ \mathrm{CB}+\end{array}$ \\
\hline & setulosa & cream to ochraceous & $0.5-2 /$ angular & $\begin{array}{l}\text { Unbranched } \\
\mathrm{IKI}+/ \mathrm{CB}+\end{array}$ \\
\hline
\end{tabular}

Table 3 Main morphological characteristics and distribution of the sequenced species of Dichomitus, Jorgewrightia, Mariorajchenbergia, Megasporia and Megasporoporia. The species in bold represent the type of each genera.

\begin{tabular}{|c|c|c|c|c|c|}
\hline Genus & Species & Spore size $(\mu \mathrm{m}) / \mathrm{shape}$ & $\begin{array}{l}\text { Crystals, hyphal } \\
\text { pegs and } \\
\text { dendrohyphidia }\end{array}$ & Distribution & Selected references \\
\hline Dichomitus & squalens & $7-10 \times 2.5-3.5 /$ cylindrical to oblong-ellipsoid & None & $\begin{array}{l}\text { Europe, possibly } \\
\text { North America }\end{array}$ & $\begin{array}{l}\text { Ryvarden \& } \\
\text { Gilbertson (1993) }\end{array}$ \\
\hline \multirow[t]{2}{*}{ Jorgewrightia } & bambusae & $\begin{array}{l}(10.5-) 11.8-14(-14.8) \times(5.5-) 5.8-6.8(- \\
7.5) / \text { ellipsoid }\end{array}$ & $\begin{array}{l}\text { Crystals, } \\
\text { dendrohyphidia }\end{array}$ & China & Wang t al. (2021) \\
\hline & cystidiolophora & $\begin{array}{l}(10-) 11.7-14.9(-15.5) \times(4-) 4.1-5.6(- \\
6) / \text { cylindrical }\end{array}$ & Crystals & China & Cui \& Dai (2007) \\
\hline
\end{tabular}


Table 3 Continued.

\begin{tabular}{|c|c|c|c|c|c|}
\hline Genus & Species & Spore size $(\mu \mathrm{m}) /$ shape & $\begin{array}{l}\text { Crystals, hyphal } \\
\text { pegs and } \\
\text { dendrohyphidia }\end{array}$ & Distribution & Selected references \\
\hline & ellipsoidea & $(11-) 12-15(-18) \times 6-8.2(-9) /$ cylindrical & All & China & Du \& Cui (2009) \\
\hline & fusiformis & $(14.1-) 15-19.8(-20.2) \times(4-) 4.2-6.8(-7) /$ fusiform & $\begin{array}{l}\text { Crystals, } \\
\text { dendrohyphidia }\end{array}$ & Malaysia & Wang et al. (2021) \\
\hline & guangdongensis & $(10-) 11-14.9(-15) \times(3-) 3.4-4.5(-4.9) /$ cylindrical & Crystals & China & Li et al. (2014) \\
\hline & hengduanensis & $\begin{array}{l}(10.8-) 11-15(-16.5) \times(4-) 4.2-5.2(- \\
6.2) / \text { cylindrical }\end{array}$ & Crystals & China & Li et al. (2014) \\
\hline & major & $15.2-20 \times 5.5-7.1 /$ cylindrical & all & China & Dai \& Li (2002) \\
\hline & rimosa & $\begin{array}{l}(16.5-) 16.8-20.2(-21) \times(4.1-) 4.3-5.5 \\
(-5.9) / \text { cylindrical }\end{array}$ & $\begin{array}{l}\text { Crystals, } \\
\text { dendrohyphidia }\end{array}$ & China & Yuan et al. (2017) \\
\hline & tropica & $\begin{array}{l}(14.2-) 14.7-18.8(-19.7) \times(4.9-) 5-6.5 \\
(-7.1) / \text { cylindrical }\end{array}$ & Crystals & China & Yuan et al. (2017) \\
\hline & violacea & $\begin{array}{l}(10-) 11-14.9(-15.2) \times(3-) 3.2-5(- \\
5.2) / \text { cylindrical }\end{array}$ & $\begin{array}{l}\text { Crystals, } \\
\text { dendrohyphidia }\end{array}$ & China & Li et al. (2014) \\
\hline & yunnanensis & $\begin{array}{l}(15.1-) 16.5-20.8(-21.5) \times(5.1-) 5.5-7.1 \\
(-7.5) / \text { cylindrical }\end{array}$ & Dendrohyphidia & China & Yuan et al. (2017) \\
\hline \multirow[t]{5}{*}{ Mariorajchenbergia } & australiae & $\begin{array}{l}(11.5-) 11.8-15(-16.5) \times(3.5-) 4-6(- \\
6.5) / \text { cylindrical }\end{array}$ & Crystals & Australia & Wang et al (2021) \\
\hline & hubeiensis & $\begin{array}{l}(9-) 10-14(-15) \times(5-) 5.6-7(-7.2) / \text { cylindrical to } \\
\text { oblong-ellipsoid }\end{array}$ & $\begin{array}{l}\text { Hyphal pegs, } \\
\text { dendrohyphidia }\end{array}$ & China & Li \& Cui (2013b) \\
\hline & pseudocavernulosa & $\begin{array}{l}(9.4-) 10.8-14(-14.8) \times(5-) 5.3-6.5(- \\
7) / \text { cylindrical to ellipsoid }\end{array}$ & Crystals, hyphal pegs & China & Li \& Cui (2013a) \\
\hline & rhododendri & $11-14 \times 6.5-8$ /ellipsoid & None & China & Dai et al. (2004) \\
\hline & subcavernulosa & $9-12.1 \times 4.2-5.2 /$ cylindrical & All & China & Dai et al. (2004) \\
\hline \multirow[t]{4}{*}{ Megasporia } & amazonica & $(9-) 10-12 \times 3.5-4 /$ ellipsoid to subcylindrical & None & $\begin{array}{l}\text { Brazil, Costa } \\
\text { Rica }\end{array}$ & $\begin{array}{l}\text { Gomes-Silva et al. } \\
\text { (2012) }\end{array}$ \\
\hline & anoectopora & 15-19 × 6-8/oblong-ellipsoid to ellipsoid & None & $\begin{array}{l}\text { Brazil, Cuba, } \\
\text { Porto Rico }\end{array}$ & Ryvarden (1984) \\
\hline & cavernulosa & $(10-) 12-16 \times 5-7 /$ cylindrical & $\begin{array}{l}\text { Dendrohyphidia, } \\
\text { difficult to observe in } \\
\text { old samples }\end{array}$ & $\begin{array}{l}\text { Brazil, possibly } \\
\text { neotropical }\end{array}$ & $\begin{array}{l}\text { Masuka \& Ryvarden } \\
\text { (1999) }\end{array}$ \\
\hline & cylindrospora & $8-10 \times 2.5-3 /$ cylindrical & None & Belize, Brazil & Ryvarden (2007) \\
\hline
\end{tabular}


Table 3 Continued.

\begin{tabular}{|c|c|c|c|c|c|}
\hline Genus & Species & Spore size $(\mu \mathrm{m}) / \mathrm{shape}$ & $\begin{array}{l}\text { Crystals, hyphal pegs } \\
\text { and dendrohyphidia }\end{array}$ & Distribution & Selected references \\
\hline & hexagonoides & $\begin{array}{l}16.6-21.8 \times 5.5-6.8 / \text { cylindrical to slightly } \\
\text { allantoid }\end{array}$ & Crystals & Argentina & Ryvarden et al. (1982) \\
\hline & mexicana & $20-26 \times 6-9 /$ cylindrical to allantoid & Hyphal pegs (few) & $\begin{array}{l}\text { Belize, } \\
\text { Honduras and } \\
\text { Mexico }\end{array}$ & Ryvarden et al. (1982) \\
\hline & variabilicolor & $(11-) 12-13 \times(2-) 3-4(-5) /$ cylindrical & Crystals & Brazil & This work \\
\hline \multirow[t]{5}{*}{ Megasporoporia } & bannaensis & $\begin{array}{l}(9.7-) 10-14(-15) \times(3.7-) 3.9-4.6(-5) / \text { cylindrical } \\
\text { to allantoid }\end{array}$ & Crystals & China & Li \& Cui (2013a) \\
\hline & inflata & $(9.8-) 10-11.8(-12) \times 3.5-4.2 /$ cylindrical & Crystals & $\begin{array}{l}\text { Malaysia and } \\
\text { Singapore }\end{array}$ & Wang et al. (2021) \\
\hline & minor & $\begin{array}{l}6-7.8(-8) \times(2.5-) 2.6-4 / \text { cylindrical to oblong- } \\
\text { ellipsoid }\end{array}$ & Hyphal pegs & China & Li \& Cui (2013a) \\
\hline & neosetulosa & $10-12 \times 3-4 /$ cylindrical & Crystals, hyphal pegs & $\begin{array}{l}\text { Brazil, possibly } \\
\text { neotropical }\end{array}$ & This work \\
\hline & setulosa & $11-17 \times 4-6 /$ cylindrical to oblong ellipsoid & Crystals, hyphal pegs & $\begin{array}{l}\text { Tanzania, } \\
\text { reported as } \\
\text { common in } \\
\text { Africa }\end{array}$ & Ryvarden et al. (1982) \\
\hline
\end{tabular}

\section{Discussion}

When studying the taxonomy and phylogeny of Megasporoporia and related genera, Li \& Cui (2013a) delimited four clades: Dichomitus s.str., Megasporia, Megasporoporia s.str. and Megasporoporiella. However, the taxonomical arrangement proposed by Li \& Cui (2013a) failed due to the inadequate choice of generic types for the new genera Megasporia and Megasporoporiella. In both cases, the specimens representing the type species were misidentified, neither did they originate from the type localities. For the present study, we included material of the type species for Megasporia and Megasporoporiella from the vicinity of the type localities. With correctly identified sequences of the type species in the dataset, our analyses show that Megasporoporiella becomes a synonym of Megasporia. For the Megasporoporiella clade, excluding the type, we instead introduce the new genus Mariorajchenbergia. Our analyses also show that a redefined Megasporia presently contains only species from the Americas. The species, excluding the type, placed in Megasporia by Li \& Cui (2013a) are here referred to the new genus Jorgewrightia. The species here selected as type of Jorgewrightia and Mariorajchenbergia were described as new species (Li \& Cui 2013a) and only M. subcavernulosa had been placed in other genera, i.e., Megasporoporiella and Cerioporus, but not fitted in these taxa according to our results (Fig. 1). Poria hexagonoides, the type species of Megasporia, had been placed in Dichomitus, Hexagonia and Megasporoporia, while Poria setulosa, type of Megasporoporia, had been placed in 
Antrodia (a brown-rot genus), Dichomitus, Elmerina (Auriculariaceae), Grammothele and Trametes. These previous placements in the polyporoid clade, as well in others, were not supported by our results (Fig. 1).

Besides genetically separated, Dichomitus, Jorgewrightia, Mariorajchenbergia, Megasporia and Megasporoporia appear to have a delimited geographical distribution. Dichomitus seems restricted to temperate and boreal areas in Eurasia and Megasporia to the neotropics, while Megasporoporia is apparently a widespread genus in tropical and subtropical regions. Jorgewrightia and Mariorajchenbergia occur above all in subtropical and temperate China, but the former also in Australia and the latter also in Malaysia.

Morphologically, Dichomitus can be differentiated from the other genera by the absence of dextrinoid and cyanophilous hyphae, lack of crystals, hyphal pegs and dendrohyphidia. The neotropical Megasporia can be distinguished from the tropical and subtropical Megasporoporia by the acyanophilous hyphae and lack of hyphal pegs in all but one species. Jorgewrightia and Mariorajchenbergia are difficult to separate, but skeletal hyphae are usually branched in the latter, while more occasionally branched in the former (Table 2). Also, dendrohyphidia and crystals are most commonly found in Jorgewrightia, while hyphal pegs are more common in Mariorajchenbergia (Table 3).

The distinction between Dichomitus and Megasporoporia s.lat. is confirmed and, thus, the synonymization of Megasporoporia to Dichomitus not supported, which is in line with previous works (Li \& Cui 2013a, b, Yuan 2013). The Dichomitus clade includes so far only the type species D. squalens (P. Karst.) D.A. Reid (Ryvarden 1991). The type is from Finland and the sequences used are from materials collected in China and Russia (Table 1), but ITS sequences from materials collected in France (KP135330) and probably Finland (AM988622, AM988623, AM988624), France (FJ349622) and Sweden (JQ518275) are also D. squalens when verified doing BLASTn searches, suggesting that the species and possibly the genus have a north temperate and boreal distribution and is absent in the tropics. However, sequences from North America that could confirm this hypothesis are lacking in GenBank.

So far, no other species belonging to Dichomitus s.str. has been sequenced, although several are still morphologically identified as such, as D. citricremeus Masuka \& Ryvarden and D. ecuadorensis Ryvarden both recorded in Brazil (Maia et al. 2015). Dichomitus citricremeus was described from Cameroon, in tropical Africa, while the Brazilian specimen (FLOR 11808) was collected in a subtropical region in south Brazil. The Brazilian material was deteriorated and, thus, the presence of the species in the country is dubious. Dichomitus ecuadoriensis was described from Ecuador and recorded twice in Brazil (FURB 55087 and URM 83056). Both the type LR 44728 (O) and URM 83056 were examined and may belong to Megasporia. The specimen URM 83056 was not sequenced, however, the 28S sequence from LR 44728 is available in GenBank (JQ780440) and clustered without support with the type material of Truncospora macrospora (JX941596) (Fig. 1). It also had high LSU similarity (98.52\%) with T. macrospora (JX941596). Sequencing the ITS region from the type is needed to evaluate the real identity of D. ecuadoriensis.

Besides the new genera and the rearrangements here proposed for Megasporia and Megasporoporia, two new species were introduced. A possible name for the new Megasporoporia neosetulosa would be Trametes subserpens Murrill, a species recorded in the Americas and listed as a synonym of $M$. setulosa, the African counterpart of M. neosetulosa, in Index Fungorum. Trametes subserpens, however, was not validly published according to the Article 38.1 (a) of Turland et al. (2018), since a description or diagnosis of the taxon was lacking. Among the synonyms listed to Megasporia cavernulosa that would fit $M$. variabilicolor neotropical distribution, Hexagonia heteropora Pat. was possibly collected in the Amazonian Venezuela (Puerto Zamuro, High Orinoco), while Poria linearis Murrill was collected in Panama, both distant from the type locality of $M$. variabilicolor and from different phytogeographical domains. In addition, $M$. variabilicolor is distantly related to H. tenuis (Fig. 1), the type species of Hexagonia.

Several species that belonged to Megasporoporia sensu Ryvarden et al. (1982) and Megasporoporiella sensu Li \& Cui (2013a) and Wang et al. (2021) have been recently transferred 
to Cerioporus Quél. (Zmitrovich 2018): Megasporoporiella cavernulosa, M. lacerata, M. pseudocavernulosa, $M$. rhododendri, and $M$. subcavernulosus, but the author did not present a clear explanation for these decisions. Through his circumscription, Cerioporus became morphologically a rather heterogeneous genus. Cerioporus is typified by Boletus squamosus Huds. (better known as Polyporus squamosus) from Germany (based on B. juglandis Schaeff.) or Hungary (according to Ryvarden 1991). The sequences used in the present work are from the USA (AFTOL ID-704) and China (Cui 10394, Cui 10595) (Table 1), but ITS sequences from materials collected in Bulgaria (HQ439363), Denmark (AF516587.1), Germany (AF516588, AF516589), Sweden (AF516590) and Russia (KM411467.1) also represent Cerioporus squamosus (Huds.) Quél. when verified doing BLASTn searches. Polyporus squamosus (AFTOL ID-704) is distantly related to Dichomitus, Jorgewrightia, Mariorajchenbergia, Megasporia and Megasporoporia (Fig. 1). By contrast, Zmitrovich (2018) kept several species in Dichomitus that now clearly belong to other genera, including D. amazonicus ( $\equiv$ Megasporia amazonica), D. anoectoporus (三 Megasporia anoectopora), D. cylindrosporus (三 Megasporia cylindrospora), D. hubeiensis (三 Mariorajchenbergia hubeiensis) and D. mexicanus (三 Megasporia mexicana) and, similarly to the reassignments suggested to Cerioporus, the author did not present reasons for these choices. Therefore, the taxonomical rearrangements proposed by Zmitrovich (2018) were not supported by our results.

This is the first molecular study of Megasporoporia s.lat. using sequences from materials collected in Brazil and Tanzania. The results provide a more natural placement for several specimens and species collected in the neotropics and support the guidelines proposed by Vellinga et al. (2015), that include (1) monophyletic genera with sufficient statistical support and based on more than one gene, (2) wide number of species, geographic coverage and type species of the studied genera, and (3) discussion of possible taxonomical rearrangements. Regarding the second guideline, we would like to emphasize that even more important is the inclusion of type specimens or at least reference specimens from or close to the type locality and similar habitat, since the use of type species based in unsuitable material has proven to cause misunderstandings in taxonomical delimitation.

\section{Acknowledgements}

We would like to thank the Instituto Chico Mendes de Conservação da Biodiversidade (ICMBio), the Instituto Brasileiro de Meio Ambiente (IBAMA) for support during the field trips; Ellen Larsson and Karl-Henrik Larsson for sequencing the neotype of Poria setulosa; Angelina M. Ottoni, Carla Santos and Nelson C. Lima-Junior for their help with DNA extraction and sequence analyses; João Oliveira, from URM, for helping with the exsiccates; Konstaze Bensch, from MycoBank, for helping with the nomenclatural changes; and the reviewers and editors of other journals who contributed with the several versions of this manuscripts in the past four years. The authors specially acknowledge Karl-Henrik Larsson for inestimable suggestions in the final version of the manuscript and for the English revision. The Coordenação de Aperfeiçoamento de Pessoal de Nivel Superior (CAPES) for the scholarship of CRSL and AMSS, RLMA to FACEPE (BFP 02072.03/20), CNPq [PPBio Semi-Árido (558317/2009-0), PROTAX (562106/2010-3), Sisbiota (563342/2010-2), PQ (307601/2015-3, 302941/2019-3)], FACEPE (ATP 0021-2.03/18), CAPES (PRINT 88887.311891/2018-00) and the Pós-Graduação em Biologia de Fungos for financing this research.

\section{References}

Binder M, Justo A, Riley R, Salamov A et al. 2013 - Phylogenetic and phylogenomic overview of the Polyporales. Mycologia 105: 1350-1373.

Bonfield JK, Smith KF, Staden R. 1995 - A new DNA sequence assembly program. Nucleic Acids Research 23: 4992-4999. 
Carlsson F, Edman M, Holm S, Eriksson AM, Jonsson BG. 2012 - Increased heat resistance in mycelia from wood fungi prevalent in forests characterized by fire: a possible adaptation to forest fire. Fungal Biol:116(10):1025-1031. Doi 10.1016/j.funbio.2012.07.005

Cui BK, Dai YC. 2007 - Polypores from Tianmushan Nature Reserve Zhejiang Province, eastern China). Mikologiya i Fitopatologiya. 41(6): 506-514.

Cui BK, Li HJ, Ji X, Zhou JL et al. 2019 - Species diversity, taxonomy and phylogeny of Polyporaceae (Basidiomycota) in China. Fungal Diversity 97(1): 137-392.

Dai YC, Li TH. 2002 - Megasporoporia major (Basidiomycota), a new combination. Mycosystema 21: 519-521.

Dai YC, Wei YL, Wang Z. 2004 - Wood-inhabiting fungi in southern China 2. Polypores from Sichuan Province. Annales Botanici Fennici 41, 319-329.

Dai YC, Wu SH. 2004 - Megasporoporia (Aphyllophorales, Basidiomycota) in China. Mycotaxon 89: 379-388.

Doi 10.1016/j.funbio.2017.05.010

Du P, Cui BK. 2009 - Two new species of Megasporoporia (Polyporales, Basidiomycota) from tropical China. Mycotaxon 110: 131-138.

Floudas D, Hibbett DS. 2015 - Revisiting the taxonomy of Phanerochaete (Polyporales, Basidiomycota) using a four gene dataset and extensive ITS sampling. Fungal Biol.: 119(8): 679-719. Doi 10.1016/j.funbio.2015.04.003

Frøslev TG, Matheny PB, Hibbett DS. 2005 - Lower-level relationships in the mushroom genus Cortinarius (Basidiomycota, Agaricales): a comparison of RPB1, RPB2 and ITS phylogenies. Molecular Phylogenetics and Evolution 37: 602-618.

Ghobad-Nejhad M, Dai YC. 2010 - Diplomitoporus rimosus is found in Asia and belongs to the Hymenochaetales. Mycologia 102: 1510-1517

Goés-Neto A, Loguercio-Leite C, Guerrero RT. 2005 - DNA extraction from frozen field-colected and dehydrated herbarium fungal basidiomata: performance of SDS and CTAB-based methods. Biotemas 18(2): 19-32.

Gomes-Silva AC, Gibertoni TB, Ryvarden L. 2012 - Resupinate poroid fungi from tropical rain forests in Brazil: two new species and new records. Mycological Progress 11: 3-9.

Hoang DT, Chernomor O, Haeseler A von, Minh BQ, Vinh LS. 2017 - UFBoot2: Improving the ultrafast bootstrap approximation. Mol Biol Evol, in press. Doi 10.1093/molbev/msx281

Justo A, Miettinen O, Floudas D, Ortiz-Santana B et al. 2017 - A revised family-level classification of the Polyporales (Basidiomycota). Fungal Biology 121: 798-824.

Kalyaanamoorthy S, Minh BQ, Wong TKF, Haeseler A von, Jermiin LS. 2017 - ModelFinder: Fast model selection for accurate phylogenetic estimates. Nature Methods, 14: 587-589. Doi 10.1038/nmeth.4285

Katoh K, Rozewicki J, Yamada KD. 2019 - MAFFT online service: multiple sequence alignment, interactive sequence choice and visualization. Briefings in Bioinformatics 20: 1160-1166. Doi 10.1093/bib/bbx108

Kumar S, Stecher G, Tamura K. 2016 - MEGA7: molecular evolutionary genetics analysis version 7.0 for bigger datasets. Molecular Biology and Evolution 33: 1870-1874.

Li HJ, Cui BK, Dai YC. 2014 - Taxonomy and multi-gene phylogeny of Datronia (Polyporales, Basidiomycota). Persoonia 32: 170-182.

Li HJ, Cui BK. 2013a - Taxonomy and phylogeny of the genus Megasporoporia and its related genera. Mycologia 105(2): 368-383.

Li HJ, Cui BK. 2013b - Dichomitus hubeiensis sp nov and a new record of Dichomitus (Basidiomycota) from China. Nordic Journal of Botany 31(1): 118-121.

Li HJ, Si J, He SH. 2016 - Daedaleopsis hainanensis sp. nov. (Polyporaceae, Basidiomycota) from tropical China based on morphological and molecular evidence. Phytotaxa 275, 294-300.

Lira CRS, Ryvarden L, Gibertoni TB. 2016 - Morphological and molecular evidences for a new species of Datroniella (Polyporales, Basidiomycota) from Brazil. Phytotaxa 280, 173-178. 
Maia LC, Junior AAC, Cavalcanti LH, Gugliotta AM et al. 2015 - Diversity of Brazilian Fungi. Rodriguésia 66(4): 1033-1045.

Masuka AJ, Ryvarden L. 1999 - Dichomitus in Africa. Mycological Research 103(9): 1126-1130.

Moncalvo JM, Lutzoni FM, Rehner SA, Johnson J, Vilgalys R. 2000 - Phylogenetic relationships of agaric fungi based on nuclear large subunit ribosomal DNA sequences. Systematic Biology 49: 278-305.

Nguyen L-T, Schmidt HA, Haeseler A von, Minh BQ. 2015 - IQ-TREE: A fast and effective stochastic algorithm for estimating maximum likelihood phylogenies. Mol Biol Evol, 32: 268-274. Doi 10.1093/molbev/msu300

Rambaut A. 2014 - FigTree v. 1.4.2. Available at http://tree.bio.ed.ac.uk/software/figtree/

Rehner SA, Buckley E. 2005 - A Beauveria phylogeny inferred from nuclear ITS and EF1-a sequences: evidence for cryptic diversification and links to Cordyceps teleomorphs. Mycologia 97: 84-98.

Ronquist F, Huelsenbeck JP. 2003 - Mrbayes 3: bayesian phylogenetic inference under mixed models. Bioinformatics 19: 1572-1574. Doi 10.1093/bioinformatics/btg180

Ryvarden L. 1984 - Type studies in the Polyporaceae 16. Species described by J.M. Berkeley either alone or with other mycologists from 1856 to 1886. Mycotaxon 20(2): 329-363

Ryvarden L. 1991 - Genera of Polypores. Synopsis Fungorum 5. Fungiflora.

Ryvarden L. 2007 - Studies in Neotropical polypores 23. New and interesting wood-inhabiting fungi from Belize. Synopsis Fungorum 23: 32-50.

Ryvarden L. 2015 - Neotropical Polypores Part 2. Synopsis Fungorum 34: 315-324.

Ryvarden L, Gilbertson RL. 1993 - European Polypores: Abortiporus - Lindtneria. Fungiflora.

Ryvarden L, Johansen I. 1980 - A Preliminary Polypore Flora of East Africa. Oslo: Fungiflora. 587-596.

Ryvarden L, Wright JE, Rajchenberg M. 1982 - Megasporoporia, a new genus of resupinate polypores. Mycotaxon 16(1): 172-182.

Smith BJ, Sivasithamparam K. 2000 - Isozymes of Ganoderma species from Australia. Mycol. Res. 104(8): 952-961.

Trifinopoulos J, Nguyen LT, von Haeseler A, Minh BQ. 2016 - W-IQ-TREE: a fast-online phylogenetic tool for maximum likelihood analysis. Nucleic Acids Res 44(W1): W232W235. Doi 10.1093/nar/gkw256

Turland NJ, Wiersema JH, Barrie FR, Greuter Wet al. 2018 - (eds.). International Code of Nomenclature for algae, fungi, and plants (Shenzhen Code) adopted by the Nineteenth International Botanical Congress Shenzhen, China, July 2017. Regnum Vegetabile 159. Glashütten: Koeltz Botanical Books. Doi 10.12705/Code.2018

Vellinga EC, Kuyper TW, Ammirati J, Desjardin DE et al. 2015 - Six simple guidelines for introducing new genera of fungi. IMA Fungus 6(2): 65-68.

Wang YR, Wu YD, Vlasák J, Yuan Y, Dai YC 2021 - Phylogenetic analysis demonstrating four new species in Megasporoporia sensu lato (Polyporales, Basidiomycota). Mycosphere 12(1), 1012-1037. Doi 10.5943/mycosphere/12/1/11

Watling R. 1969 - Colour identification chart. Her Majesty's Stationary Office, Edinburgh (Scotland).

White TJ, Bruns T, Lee S, Taylor JW. 1990 - Amplification and direct sequencing of ribosomal RNA genes for phylogenetics. PCR Protocols: A Guide to Methods and Applications 8: 315322.

Yuan H-S. 2013 - Dichomitus sinuolatus sp nov (Basidiomycota, Polyporales) from China and a key to the genus. Nova Hedwigia 97(3-4): 495-501.

Yuan Y, Ji XH, Chen JJ, Dai YC. 2017 - Three new species of Megasporia (Polyporales, Basidiomycota) from China. MycoKeys 20: 37-50. Doi 10.3897/mycokeys.20.11816

Zhao CL, Cui BK. 2012 - A new species of Perenniporia (Polyporales, Basidiomycota) described from southern China based on morphological and molecular characters. Mycological Progress 11, 555-560. Doi 10.1007/s11557-011-0770-1 
Zhou JL, Cui BK. 2017 - Phylogeny and taxonomy of Favolus (Basidiomycota). Mycologia 109, 766-779. Doi 10.1080/00275514.2017.1409023

Zhou JL, Zhu L, Chen H, Cui BK. 2016 - Taxonomy and Phylogeny of Polyporus Group Melanopus (Polyporales, Basidiomycota) from China. PLoS One 11(8):e0159495.

Zhou XS, Dai, YC. 2008 - A new species of Megasporoporia (Polyporales, Basidiomycota) from China. Mycological Progress 7(4): 253-255.

Zmitrovich IV, KovalenkoAE. 2016 - Lentinoid and Polyporoid Fungi, Two Generic Conglomerates Containing Important Medicinal Mushrooms in Molecular Perspective. IntJMedMushrooms 18: 23-38.

Zmitrovich IV. 2018 - Conspectus systematis Polyporacearum v. 1.0. Folia Cryptogamica Petropolitana 6: 3-145. 